\title{
Quantifying climate change mitigation potential in the United States Great Plains wetlands for three greenhouse gas emission scenarios
}

\author{
Kristin Byrd • Jamie Ratliff • Norman Bliss • \\ Anne Wein • Ben Sleeter • Terry Sohl • Zhengpeng Li
}

Received: 7 March 2013 / Accepted: 8 August 2013 /Published online: 10 September 2013

C The Author(s) 2013. This article is published with open access at Springerlink.com

\begin{abstract}
We examined opportunities for avoided loss of wetland carbon stocks in the Great Plains of the United States in the context of future agricultural expansion through analysis of land-use land-cover (LULC) change scenarios, baseline carbon datasets and biogeochemical model outputs. A wetland map that classifies wetlands according to carbon pools was created to describe future patterns of carbon loss and potential carbon savings. Wetland avoided loss scenarios, superimposed upon LULC change scenarios, quantified carbon stocks preserved under criteria of carbon densities or land value plus cropland suitability. Up to $3420 \mathrm{~km}^{2}$ of wetlands may be lost in the region by 2050 , mainly due to conversion of herbaceous wetlands in the Temperate Prairies where soil organic carbon (SOC) is highest. SOC loss would be approximately $0.20 \pm 0.15$ megagrams of carbon per hectare per year $\left(\mathrm{MgC} \mathrm{ha} \mathrm{yr}^{-1}\right)$, depending upon tillage practices on converted wetlands, and total ecosystem carbon loss in woody wetlands would be approximately $0.81 \pm 0.41 \mathrm{MgC} \mathrm{ha}^{-1} \mathrm{yr}^{-1}$, based on biogeochemical model results. Among wetlands vulnerable to conversion, wetlands in the Northern Glaciated Plains and Lake Agassiz Plains ecoregions exhibit very high mean SOC and on average, relatively low land values, potentially creating economically competitive opportunities for avoided carbon loss. This mitigation scenarios approach may be adapted by managers using their own preferred criteria to select sites that best meet their objectives. Results can help prioritize field-based assessments, where site-level investigations of carbon stocks, land value, and consideration of local priorities for climate change mitigation programs are needed.
\end{abstract}

Work performed under USGS contract G08PC91508.

K. Byrd $(\bowtie) \cdot J$. Ratliff $\cdot$ A. Wein $\cdot$ B. Sleeter

U.S. Geological Survey Western Geographic Science Center, 345 Middlefield Road, MS-531, Menlo Park, CA 94025, USA

e-mail: kbyrd@usgs.gov

N. Bliss

ARTS, contractor to U.S. Geological Survey Earth Resources Observation and Science Center, Sioux Falls, SD, USA

T. Sohl

U.S. Geological Survey Earth Resources Observation and Science Center, Sioux Falls, SD, USA

Z. $\mathrm{Li}$

University of Maryland, College Park, MD, USA 
Keywords Wetland avoided loss · Biological carbon sequestration · Land-use land-cover change $\cdot$ Soil organic carbon $\cdot$ Woody biomass $\cdot$ Agricultural land value

\section{Introduction}

From 1850 to 2000 , global land-use change caused a net release of carbon to the atmosphere that represented 28 to $40 \%$ of all anthropogenic carbon emissions, with the greatest source coming from conversion to cropland (Houghton 2010). Consequently, conservation of lands with high carbon stocks and restoration of degraded lands to sequester carbon and reduce greenhouse gas emissions (GHG) provide options for climate change mitigation in the short term while other technological solutions evolve (Lal 2004). However, these options compete with continued demand for land-use (USEPA 2005). We examine future potential demand for agricultural expansion and opportunities for climate change mitigation in the context of wetlands in the United States Great Plains using products from the United States Geological Survey's (USGS) national carbon sequestration assessment of ecosystem carbon stocks, carbon sequestration, and greenhouse-gas fluxes under present conditions and future scenarios (hereafter referred to as the USGS assessment) (Zhu et al. 2010).

The Great Plains grasslands area has been reduced more than any other ecosystem in North America as a result of increasing agriculture (Samson and Knopf 1994). This loss has included the reduction of wetland area greater than $50 \%$ in most states (Dahl and Johnson 1991). Draining wetlands results in lost sequestration capacity as well as oxidation of extant soil carbon pools, both positive radiative forcings (Ramaswamy et al. 2001; Bridgham et al. 2006). In the prairie pothole region in the northern Great Plains, for example, agricultural conversion has led to the average loss of 10.1 megagrams per hectare $\left(\mathrm{Mg} \mathrm{ha}^{-1}\right)$ of soil organic carbon (SOC) over 16 million hectares (Euliss et al. 2006).

The potential for new carbon offset projects to mitigate climate change has grown with emerging carbon markets. These projects are considered an opportunity to protect or restore threatened ecosystems that would otherwise be degraded or converted (Ducks Unlimited Inc. et al. 2009; Crooks et al. 2010; Harvey et al. 2010; Climate Action Reserve 2011). Projects have been proposed for tidal wetlands that include avoided wetland loss, wetland restoration, wetland management and wetland creation, and are based on similar principles established for existing national and international forestry greenhouse gas (GHG) offset protocols (Crooks et al. 2010). Restoration or creation may be justified in estuarine wetlands where low methane emissions and enhanced sequestration lower net radiative forcing. In freshwater wetlands, outcomes are uncertain; restoration or creation may increase net radiative forcing with increased methane emissions (Bridgham et al. 2006) or may have the potential to become net radiative sinks (Badiou et al. 2011; Mitsch et al. 2012).

Numerous wetland and grassland habitats on private lands have been protected and restored throughout the Great Plains through programs sponsored by federal, state, and private entities. The most notable programs include the U.S. Department of Agriculture Cropland Reserve Program (CRP) and Wetlands Reserve Program (WRP), the U.S. Fish and Wildlife Service Partners for the Fish and Wildlife Program, and land protection programs of Ducks Unlimited Inc., a non-governmental organization (Badiou et al. 2011; USDA Natural Resources Conservation Service 2012). Particular to the Great Plains, DU has partnered in its easement program with the Plains Carbon Dioxide Reduction $\left(\mathrm{PCO}_{2} \mathrm{R}\right)$ Partnership, a collaboration of over 80 U.S. and Canada stakeholders to protect 10,643 ha of native grassland in the prairie pothole region under perpetual conservation easements that will be donated to the U.S. Fish and Wildlife Service and will create a bank of SOC (Ducks Unlimited Inc. et al. 2009). 
Despite these successful efforts to protect and restore wetlands, demand for agricultural development in the Great Plains continues to grow. For example, ethanol production increase of 9 billion gallons between 2000 and 2009 has driven higher demand for corn (Zea mays) (Wallander et al. 2011). High prices for corn have contributed to large increases in land planted to corn, which at 96.4 million acres (39 million ha) in 2012 was at its highest level since 1937 (USDA National Agricultural Statistics Service 2012a). At the same time, agricultural land value has continued to increase. The average U.S. farm real estate value, adjusted for inflation, increased from $\$ 817$ in 1969 to \$2074 per acre in 2011 (Nickerson et al. 2012). From 2006 to 2010, cropland cash rents increased $\$ 2.50$ per acre to $\$ 71.00$ in the northern plains region of the U.S. (Kansas, Nebraska, North Dakota, South Dakota) and $\$ 3.00$ per acre to $\$ 152.00$ in the Corn Belt region of the U.S. (Illinois, Indiana, Iowa, Missouri, Ohio) where slightly more than one half of cash rented cropland acreage in the United States is located. The cash rent paid for pasture in the corn belt region decreased $\$ 1.50$ to $\$ 29.50$ per acre, but is the highest cash rent paid for pasture in the U.S. (USDA National Agricultural Statistics Service 2010).

Rising crop prices, emergence of genetically modified crops and new farming techniques have made farming on marginal lands more profitable, increasing the likelihood of their conversion (U.S. Government Accountability Office 2007; Gleason et al. 2011). At the same time, land costs and suitability for agricultural use are positively correlated, meaning that high quality lands are typically more expensive to acquire for conservation purposes through easements or fee title than low vulnerability sites with poor land quality (Newburn et al. 2005, 2006; Merenlender et al. 2009). Research is needed to identify regions suitable for carbon offsets that consider threat of conversion as well as cost (Merenlender et al. 2009). By establishing offset programs in lower-cost regions, the overall cost of achieving a given emission reduction goal can be reduced (Kollmuss et al. 2010).

In this paper we assess future opportunities for climate change mitigation in Great Plains wetlands based on the USGS land-use land-cover (LULC) change scenarios, and consider suitability of land for competing uses. We focus our analysis on opportunities for avoided loss of carbon stocks, given the variability of GHG emission increases associated with the creation and restoration of freshwater wetlands. Our study addresses three main questions: 1) under LULC change scenarios, which wetland SOC and woody biomass carbon pools are potentially impacted, and how do these pools vary by wetland type, region, and land value and suitability for farmland? 2) under two sets of wetland avoided loss scenarios, what is the extent and distribution of wetland SOC and woody biomass pools that could be protected? 3 ) for geographic regions of the Great Plains and for wetland types with the greatest likelihood of conversion, what is the potential loss in wetland SOC and woody biomass that may occur if mitigation is not implemented based on biogeochemical model results?

\section{Methods}

\subsection{Background on the USGS assessment}

Future scenarios of LULC change in the Great Plains of the U.S. have been developed as part of a national carbon sequestration assessment. The assessment, required by the U.S. Congress (Energy Independence and Security Act of 2007) and conducted by the USGS, used a methodology that linked ecosystem carbon models to separate models of wildfires and LULC changes, and produced spatially and temporally explicit carbon stock and flux estimates (Zhu et al. 2010). Future potential LULC change was based on a set of scenarios 
from three United Nations Intergovernmental Panel on Climate Change (IPCC) Special Report on Emission Scenarios (SRES) (Nakicenovic and Swart 2000): A2 (emphasizes economic development with a regional focus), A1B (emphasizes economic development with a global orientation), and B1 (emphasizes environmental sustainability with a global orientation) (Zhu et al. 2011).

To develop LULC change scenarios that were logically consistent with SRES storylines, Sleeter and others (2012) took projected national LULC change data from the Integrated Model to Assess the Global Environment (IMAGE) (Strengers et al. 2004) and allocated them to U.S. Environmental Protection Agency (EPA) Level III ecoregions based on landuse histories from the USGS Land Cover Trends project (Loveland et al. 2002), as well as expert knowledge. The LULC classification scheme of the scenarios closely followed the National Land Cover Database (NLCD) (Vogelmann et al. 2001; Homer et al. 2007) and includes broad classes such as cropland, hay/pasture, development, grassland, herbaceous wetlands and woody wetlands.

The USGS used a probabilistic LULC model, FOREcasting SCEnarios of land-use change (FORE-SCE) to distribute future regional LULC change on the landscape for each LULC change scenario (Sohl and Sayler 2008; Sohl et al. 2012). The allocation was based on probabilities of occurrence determined by present-day LULC associations with biophysical and socioeconomic characteristics of the landscape, such as slope, elevation, soil carbon, climate and distance to roads and cities. Model outputs are maps of LULC change generated yearly from 2006 to 2050 at a spatial resolution of $250 \mathrm{~m}$.

Carbon dynamics and GHG fluxes between the land and the atmosphere under LULC change, climate change, and land management scenarios were estimated using three ecosystem models: the Erosion-Deposition-Carbon Model (EDCM) (Liu et al. 2003), the CENTURY model (Parton et al. 1987, 1993), and a spreadsheet model (Zhu et al. 2010). Using datasets for LULC change, simulations of areas burned by wildland fires, agricultural land management, climate, and other biophysical data, the three models were run for each of three IPCC-SRES scenarios and for one Global Climate Model (MIROC 3.2-medres) (Zhu et al. 2011). In this study we utilize outputs from one model - EDCM - because of its approach to modeling soil carbon dynamics.

\subsection{Study area}

The Great Plains region of the U.S. is characterized by a continental climate with cold winters and warm summers, and a moisture gradient that increases from west to east, from less than 380 millimeters $(\mathrm{mm})$ of rain annually to $640 \mathrm{~mm}$. Historically the Great Plains was dominated by native prairie grassland communities defined by this rainfall gradient. In the west, short-grass prairie occurs in the rain shadow of the Rocky Mountains, while mixed-grass prairie occurs in the central Great Plains and tall-grass prairie occurs in the wetter eastern region. Deep, black soils (Mollisols) are dominant in the Great Plains and contain high organic matter in the more humid eastern region. Given that these soils are highly productive, the prairie grasslands are among the largest farming and ranching areas in the world. With agricultural conversion, the short-, mixedand tall-grass prairies now correspond to the western rangelands, the wheat (Triticum spp.) belt and the corn/soybean (Glycine max) regions, respectively (Commission for Environmental Cooperation et al. 2008; Encyclopædia Britannica Online 2013). The Great Plains region has been divided into three EPA level II ecoregions, which are each subdivided into four to eight Level III ecoregions (Omernik 1987, 1995) (Fig. 1). Level II ecoregions include Temperate Prairies to the north, West-Central Semi-Arid Prairies to the west, and South Central Prairies and Southern Texas Plains (South Central Semi-Arid Prairies, from here forward) to the south. 


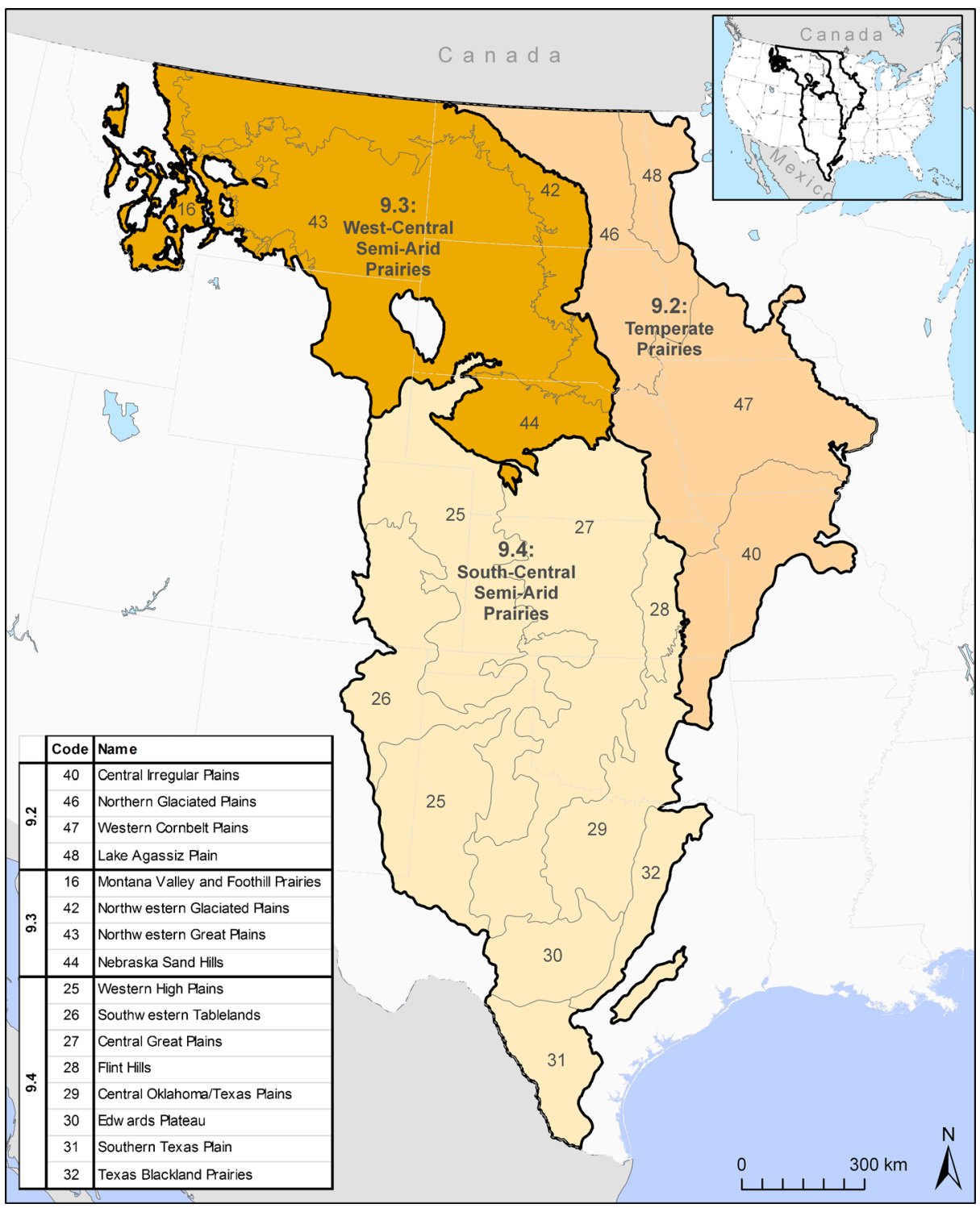

Fig. 1 Map of U.S. Great Plains level II and level III ecoregions

Each level II ecoregion contains several distinct freshwater wetland ecosystems. In the Temperate Prairies, the prairie pothole system, depressional wetlands formed by glaciers during the Pleistocene era, dominates the Northern Glaciated Plains and Lake Agassiz Plain level III ecoregions, which also contain some peatlands. Also in the Temperate Prairies, the eastern floodplain forests are common wetland types in the Central Irregular Plains and Western Cornbelt Plains level III ecoregions. In the West-Central Semi-Arid Prairies, the Nebraska Sand Hills level III ecoregion contains abundant depressional wetlands, while the Montana Valley and Foothill Prairie, Northwestern Glaciated Plains and Northwestern Great 
Plains level III ecoregions all support western riparian woodland and shrubland. The South Central Semi-Arid Prairies contain western riparian woodland in the Central Great Plains and Central Oklahoma/Texas Plains level III ecoregions, while playas (seasonal depressional wetlands) are common in the Southwestern Tablelands and Western High Plains level III ecoregions (NatureServe 2011; LANDFIRE 2012). While these wetland types vary by vegetation communities, hydrology and geomorphology, they may also be described and mapped in carbon-relevant terms.

\subsection{Wetland carbon map}

In a synthesis of literature and soils databases, Bridgham and others (2006) estimated the carbon balance of North American wetlands. To make estimates of wetland carbon pools and flux, the Bridgham team considered three categories of wetlands based upon major ecological differences that drive carbon cycling: 1) Peatlands [40 centimeters ( $\mathrm{cm})$ or more of surface organic matter with and without permafrost]; 2) Freshwater mineral soil (FWMS) wetlands (less than $40 \mathrm{~cm}$ of surface organic matter); and 3) Estuarine wetlands of three types: those dominated by herbaceous vegetation (tidal marshes), mangroves, and unvegetated areas (mud flats).

While estimates of carbon pools and flux were attributed to the land area of each wetland type in the Bridgham study described above, the data were not spatially explicit. We developed a wetland map of the Great Plains ecoregion that differentiates these carbon-relevant wetland types (Fig. 2). Our wetland map was derived from the USGS assessment baseline landcover

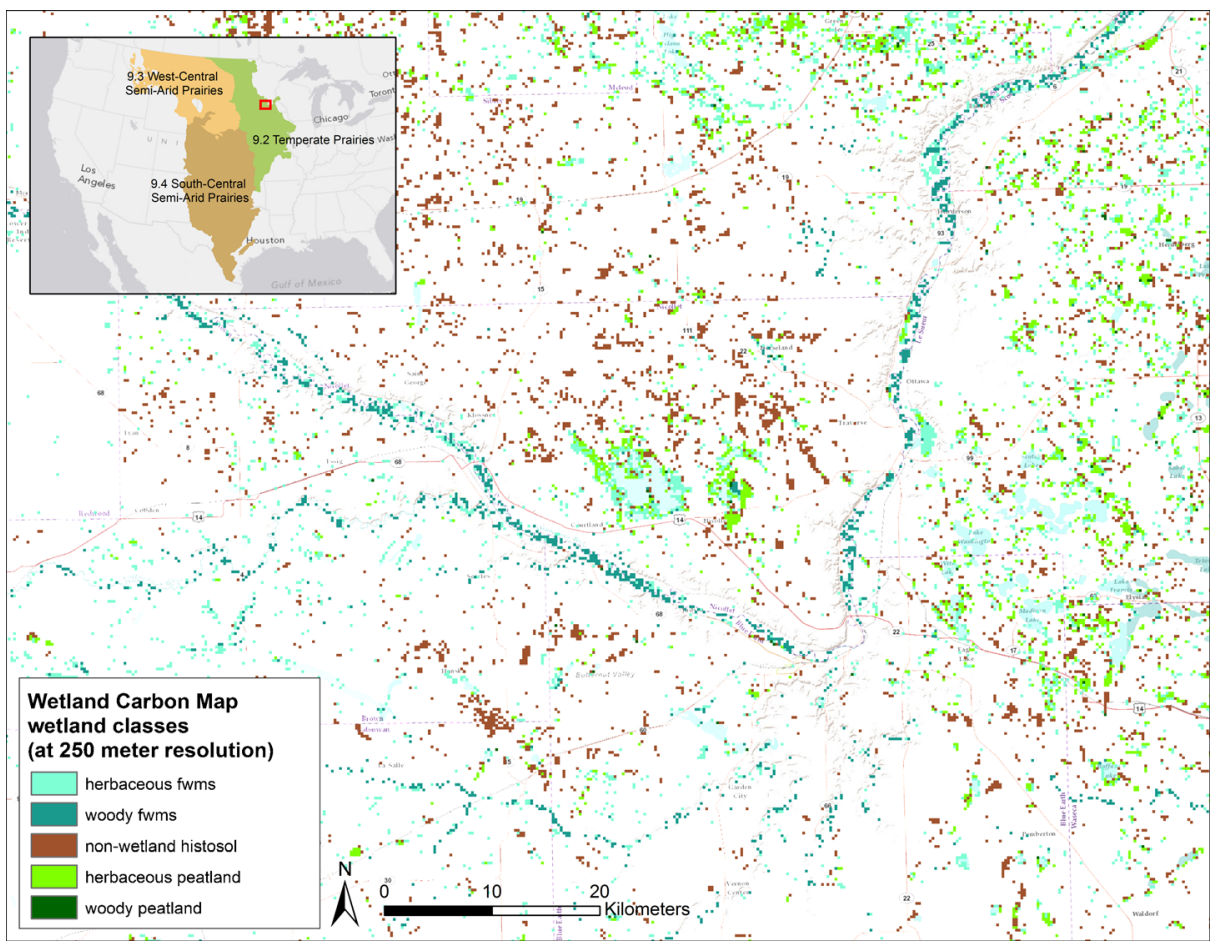

Fig. 2 Wetland Carbon Map. Wetlands classified into carbon-relevant classes as described in Bridgham and others (2006). FWMS freshwater mineral soil 
data, which was a slightly modified version of the 1992 NLCD (Vogelmann et al. 2001) at 250 meter $(\mathrm{m})$ resolution, and contained two wetland classes - herbaceous wetlands and woody wetlands. We reclassified these wetlands into new classes of herbaceous peatlands, herbaceous FWMS, woody peatlands, and woody FWMS. Peatlands were identified by using the U.S. Department of Agriculture (USDA) Soil Survey Geographic Database (SSURGO) at 250-m resolution to generate a map of the sum of the component percentages for histosols, histic modifiers, and peat and muck (Soil Survey Staff 2009a). Wetlands pixels with the percentage of peatlands more than $50 \%$ were labeled peatlands. A non-wetland peatland class was also identified for NLCD land covers that were not wetlands, but had peatland characteristics, likely representing areas that were historically wetlands, or are wetlands that have been misclassified as something else.

\subsection{Scenarios of LULC change}

By analyzing the FORE-SCE LULC change model outputs, we identified wetland pixels that were converted to cropland, hay/pasture, or other LULC classes at some time between 2010 and 2050 for SRES A2, A1B and B1. Change in wetland area and proportion of wetlands converted in the 40 year time period were calculated by level III ecoregion and wetland type.

\subsection{Land attribute data}

Wetland pixels converted to other LULC classes in the LULC change model for SRES A2, $\mathrm{A} 1 \mathrm{~B}$ and B1 were labeled with additional biophysical and economic attributes. The additional attributes included: level II ecoregion, level III ecoregion, year of conversion, LULC class after conversion, SSURGO SOC to $20 \mathrm{~cm}$ depth, SSURGO land capability class, live aboveground biomass, non-irrigated cropland cash rent value, and where available, EDCM modeled outputs for SOC to $20 \mathrm{~cm}$ and total ecosystem carbon.

\subsubsection{SSURGO}

The SSURGO database (Soil Survey Staff 2009a) was used to calculate ecologically active stocks of SOC near the surface (0 to $20 \mathrm{~cm}$ depths). Where the SSURGO data were incomplete, gaps were filled from the State Soil Geographic (STATSGO2) database (Soil Survey Staff 2009b). Some attribute errors in horizon depths, component percentages, or missing rock fragment information were corrected with reasonable estimates, to provide the best estimate of the SOC for a given land area. The estimate of SOC for a SSURGO map unit was based on only the wetland components. Soils with a high potential for being wetland or former wetland were selected as those having a soil order of Histosols or a histic modifier in another soil order, or a classification in-lieu of texture of peat or muck. This calculation of SOC stocks represents a good estimate for general conditions in the time during which the database was developed (the 1970s to the 2000s) but does not represent a specific point in time. Details of the SOC calculation from SSURGO data are given by Bliss (2003).

The SSURGO data on land capability class were used as an indicator of suitability for cropland. Class 1 land has few limitations for cropland, and classes 2 through 4 have moderate to very severe limitations for cropland (e.g., erosion hazard), but even class 4 land may actually be used as cropland. Class 5 has limitations that are difficult to remove (e.g., wetness). Classes 6 to 8 are not suitable for cropland.

The SSURGO data are originally in vector format, and were rasterized to $30 \mathrm{~m}$ resolution, and resampled to the $250 \mathrm{~m}$ resolution used in this study. Many of the map units are much 
larger than the $250 \mathrm{~m}$ resolution pixels, and wetlands are sometimes a minor component of the landscape. Therefore, although the calculations using the pixel size and the sum of component percentages representing wetlands allow accurate estimates of potential wetland areas, there may be cases in which a particular pixel in the land cover database or FORESCE modeling that represents a wetland will not coincide with a SSURGO representation of a potential wetland.

\subsubsection{Aboveground live biomass carbon}

Aboveground live biomass carbon was modeled for the USGS assessment from USDA Forest Service, Forest Inventory and Analysis (FIA) biomass data (Blackard et al. 2008) and NLCD land cover data (Zhu et al. 2011). These data were used to represent standing woody biomass $\mathrm{C}$ stocks in woody wetlands.

\subsubsection{EDCM SOC and total ecosystem carbon outputs}

We used the EDCM top $20 \mathrm{~cm}$ SOC output variable to track change in wetland SOC after conversion to cropland or hay/pasture. We used the EDCM total ecosystem carbon (TEC) output variable to track change in woody biomass $\mathrm{C}$ plus SOC after conversion to cropland or hay/pasture (Liu et al. 2003, 2012b; Zhu et al. 2011). EDCM adopts a structure of multiple soil layers to account for SOC dynamics in the whole soil profile and to track the impact of soil erosion and deposition. For the USGS assessment, EDCM was run with a $10 \times 10$ systematic subsample factor to ensure adequate time for processing, generating statistics, and calibrating the estimates. Consequently results are based on a systematic sample of $1 \%$ of the total pixels (Liu et al. 2012a).

\subsubsection{USDA cash rents for non-irrigated agriculture}

This variable represents an indicator of agricultural land value that is collected in a consistent format across the Great Plains region. The USDA Cash Rents Survey provides the basis for county estimates of the current year's cash rent paid for irrigated cropland, non-irrigated cropland, and pasture (USDA National Agricultural Statistics Service 2012b; USDA National Agricultural Statistics Service 2012c). We used the non-irrigated cropland data for this study because it was a more extensive dataset and available more consistently at the county level than the irrigated cropland dataset.

\subsection{Carbon stocks impacted}

We explored geographical patterns of wetland carbon stocks with the potential for conversion by calculating average SOC and woody biomass $\mathrm{C}$ for wetlands converted in the A1B scenario. Average carbon stocks were calculated by wetland type, level III ecoregion, nonirrigated land rent value, and land capability class. We applied this analysis to wetlands converted in the A1B scenario, as this provided the largest dataset of wetlands across a greater extent compared to the other scenarios.

\subsection{Scenarios of avoided wetland loss}

We conducted a sensitivity analysis to understand how the area and distribution of land set aside for wetlands can influence the effectiveness of climate change mitigation opportunities. 
Knowing that land area reserved for carbon sequestration and enhancement is limited by competing demands for agriculture, development, and other uses, we developed and analyzed multiple avoided loss scenarios that assigned incremental areal and spatial allocation of land for wetland carbon avoided loss.

To conduct the sensitivity analysis, we generated two sets of avoided loss scenarios that were superimposed on the SRES LULC change scenarios A1B and A2. In each case of the sensitivity analysis we assumed that a certain proportion and criteria of wetlands converted in the SRES LULC change scenarios is prevented from conversion in the avoided loss scenario. The two scenario sets included the carbon scenarios based on SOC and woody biomass $\mathrm{C}$ values, and the economic scenarios based on land rent and land suitability values. In the B1, environmental scenario, relatively few wetlands were lost, and so we did not consider avoided loss mitigation in this case. The avoided loss scenarios apply to all wetlands converted in the Great Plains LULC change scenarios A1B and A2 from years 2010 to 2050. Avoided loss of SOC and woody biomass C were calculated for each scenario. Scenarios are described below.

\subsubsection{Carbon scenarios}

1) Wetlands with the highest SOC stock: avoidance of a) $10 \%$ and b) $25 \%$ of all wetlands with the highest SOC in the top $20 \mathrm{~cm} ; 2$ ) Wetlands with the lowest SOC stock: avoidance of a) $10 \%$ and b) $25 \%$ of all wetlands with the lowest SOC in the top $20 \mathrm{~cm}$; 3) Wetlands with the highest woody biomass $\mathrm{C}$ stock: avoidance of a) $10 \%$ and b) $25 \%$ of all wetlands with the highest woody biomass $\mathrm{C} ; 4)$ Wetlands with the lowest woody biomass $\mathrm{C}$ stock: avoidance of a) $10 \%$ and b) $25 \%$ of all wetlands with the lowest woody C.

\subsubsection{Economic scenarios}

1) Wetlands with the highest cropland rent value: avoidance of a) $10 \%$ and b) $25 \%$ of all wetlands with the largest non-irrigated land rent value and a land capability class of 1 or 2 ;

2) Wetlands with the lowest cropland rent value: avoidance of a) $10 \%$ and b) $25 \%$ of all wetlands with the lowest non-irrigated land rent value and a land capability class greater than 2.

Wetlands in the economic scenarios were divided based on this land capability reclassification to generate subgroups with relatively equal sample numbers. Using the selected wetlands in each scenario, the average and total sum of wetland SOC and woody biomass $\mathrm{C}$ were calculated for each level III ecoregion.

\subsection{Case studies of potential carbon loss}

As a case study, we modeled potential carbon loss from wetland conversion for herbaceous FWMS wetlands and woody FWMS wetlands in the Temperate Prairies only because these groups were subject to the most conversion in the Great Plains. Given that one percent of pixels were included in the EDCM model run, a subset of wetland pixels were characterized with the modeled SOC and TEC outputs. To track changes over time in carbon stocks after conversion, we identified wetland pixels with EDCM outputs that were converted at some point between 2010 and 2020 and remained in the converted land use until 2050 by the LULC change model. For these pixels we calculated the mean and variance of the differences in SOC and TEC (for woody wetland pixels) over 30 years and used them for the analysis. 


\section{Results}

\subsection{Scenarios of LULC change}

In general, the largest area of wetlands subject to conversion was located in the Temperate Prairies. Wetland losses occur almost exclusively due to agricultural conversion in all ecoregions and all wetland types. In the A1B scenario, the Temperate Prairies lost 228,606 ha, the West-Central Prairies lost 65,383 ha, most of which were herbaceous FWMS wetlands, and the South-Central Prairies lost 47,975 ha, which were predominately woody FWMS wetlands (Table 1). The total loss in A1B was 341,964 ha. In the A2 scenario, the Temperate Prairies lost 95,025 ha, the West-Central Prairies lost 27,563 ha, and the South-Central Prairies lost 43,001 ha, for a total loss of 165,589 ha. In contrast, in the B1 scenario the Temperate Prairies experience the greatest gains in wetlands with an increase of 383,463 ha, mostly in herbaceous FWMS wetlands. The West-Central Prairies gained 45,556 ha and the South-Central Prairies gained 77,269 ha, mostly in woody FWMS wetlands.

\subsection{Carbon stocks impacted}

\subsubsection{Soil organic carbon}

For wetlands converted under the A1B scenario, SOC in the top $20 \mathrm{~cm}$ of the soil profile exhibits a strong directional trend from the lowest values in the southwestern-most ecoregions to the highest values in the northeastern-most ecoregions (Table 2). The highest SOC is found in the herbaceous peatlands of the Temperate Prairies, specifically the Northern Glaciated Plains, Lake Agassiz Plain, and Western Cornbelt Plain level III ecoregions. Highest SOC averages range from 160 to $210 \mathrm{MgC} \mathrm{ha}^{-1}$, with standard errors reaching $14.2 \mathrm{MgC} \mathrm{ha}^{-1}$. The wetlands with the highest SOC are on land unsuitable for cultivation (land capability class 6-8) with a wide range of land rent values. An exception is a subset of herbaceous peatlands in the Western Cornbelt Plains that have high cropland rent values and have only some limitations to cultivation (land capability class 1-4).

\subsubsection{Woody biomass carbon}

The distribution of woody biomass $\mathrm{C}$ pools is more scattered geographically across the Great Plains, with the highest average values in the Central Great Plains level III ecoregion and the Central Irregular Plains level III ecoregion (Table 3). Highest aboveground biomass averages range from 26.75 to $30.38 \mathrm{MgC} \mathrm{ha}^{-1}$, with standard errors reaching $1.99 \mathrm{MgC} \mathrm{ha}^{-1}$. These high-biomass woody wetlands, most of which have mineral soils, are generally located on lands unsuitable for cultivation (land capability class 6-8) or have other limitations to their use as cropland (class 5). The exception is woody wetlands in the Central Irregular Plains level III ecoregion with a land capability class of 1 to 4 . Cropland rents for the highest biomass woody wetlands span a range from low to high.

\subsection{Scenarios of avoided loss}

Given the potential magnitude of conversion from wetlands to other land uses as defined by the LULC change model outputs, it is uncertain what factors will influence decisions regarding 
Table 1 Wetland area net conversions in hectares and percent change to/from selected land use-land cover classes from 2010 to 2050 for the A1B, A2, and B1 Special Report on Emission Scenarios

\begin{tabular}{|c|c|c|c|c|c|c|c|c|c|}
\hline \multirow[t]{2}{*}{ Wetland class } & \multirow[t]{2}{*}{ Ecoregion } & \multicolumn{2}{|c|}{ Agriculture } & \multicolumn{2}{|c|}{ Hay/Pasture } & \multicolumn{2}{|c|}{ Other classes } & \multicolumn{2}{|l|}{ Total } \\
\hline & & Area (ha) & Percent ${ }^{\mathrm{a}}$ & $\begin{array}{l}\text { Area } \\
\text { (ha) }\end{array}$ & Percent & $\begin{array}{l}\text { Area } \\
\text { (ha) }\end{array}$ & Percent & Area (ha) & Percent \\
\hline
\end{tabular}

A) SRES A1B

Herbaceous 9.2

FWMS 9.3

9.4

Herbaceous 9.2

9.4

Woody $\quad 9.2$

FWMS $\quad 9.3$

$\begin{array}{ll} & 9.4 \\ \text { Woody } & 9.2\end{array}$

Peatland 9.3

9.4

B) SRES A2

Herbaceous 9.2

FWMS $\quad 9.3$

$\begin{array}{ll} & 9.4 \\ \text { Herbaceous } & 9.2\end{array}$

Peatland 9.3

9.4

Woody $\quad 9.2$

FWMS 9.3

$\begin{array}{cc} & 9.4 \\ \text { Woody } & 9.2 \\ \text { Peatland } & 9.3\end{array}$

9.4

C) SRES B1

Herbaceous 9.2

FWMS 9.3

$\begin{array}{rr} & 9.4 \\ \text { Herbaceous } & 9.2\end{array}$

Peatland 9.3

9.4

Woody $\quad 9.2$

FWMS $\quad 9.3$

$\begin{array}{cr} & 9.4 \\ \text { Woody } & 9.2 \\ \text { Peatland } & 9.3\end{array}$

9.4
Peatland 9.3

$\begin{array}{llllllll}-115,644 & -11 \% & -27,838 & -3 \% & -644 & 0 \% & -144,125 & -13 \% \\ -26,475 & -4 \% & -27,369 & -4 \% & -1,169 & 0 \% & -55,013 & -8 \% \\ -10,006 & -3 \% & -1,094 & 0 \% & 56 & 0 \% & -11,044 & -4 \% \\ -10,363 & -10 \% & -488 & 0 \% & -50 & 0 \% & -10,900 & -11 \% \\ -38 & 0 \% & -600 & -2 \% & 0 & 0 \% & -638 & -2 \% \\ 0 & 0 \% & 0 & 0 \% & 0 & 0 \% & 0 & 0 \% \\ -49,119 & -9 \% & -19,631 & -4 \% & -1,106 & 0 \% & -69,856 & -13 \% \\ -7,506 & -4 \% & -956 & -1 \% & -1,250 & -1 \% & -9,713 & -6 \% \\ -31,219 & -29 \% & -6,088 & -6 \% & 375 & 0 \% & -36,931 & -34 \% \\ -3,544 & -12 \% & -181 & -1 \% & 0 & 0 \% & -3,725 & -12 \% \\ 0 & 0 \% & -13 & 0 \% & -6 & 0 \% & -19 & 0 \% \\ 0 & 0 \% & 0 & 0 \% & 0 & 0 \% & 0 & 0 \%\end{array}$$$
\begin{array}{llllllll}
-40,700 & -4 \% & -8,613 & -1 \% & -1,369 & 0 \% & -50,681 & -5 \% \\
-13,481 & -2 \% & -9,838 & -1 \% & -406 & 0 \% & -23,725 & -3 \% \\
-4,663 & -2 \% & -375 & 0 \% & 25 & 0 \% & -5,013 & -2 \% \\
-5,156 & -5 \% & -256 & 0 \% & -63 & 0 \% & -5,475 & -6 \% \\
-13 & 0 \% & -188 & -1 \% & 0 & 0 \% & -200 & -1 \% \\
0 & 0 \% & 0 & 0 \% & 0 & 0 \% & 0 & 0 \% \\
-25,025 & -5 \% & -10,144 & -2 \% & -1,756 & 0 \% & -36,925 & -7 \% \\
-2,631 & -2 \% & -413 & 0 \% & -594 & 0 \% & -3,638 & -2 \% \\
-31,888 & -34 \% & -6,100 & -6 \% & 0 & 0 \% & -37,988 & -40 \% \\
-1,806 & -6 \% & -138 & 0 \% & 0 & 0 \% & -1,944 & -6 \% \\
0 & 0 \% & 0 & 0 \% & 0 & 0 \% & 0 & 0 \% \\
0 & 0 \% & 0 & 0 \% & 0 & 0 \% & 0 & 0 \%
\end{array}
$$

\begin{tabular}{llllllll}
273,300 & $25 \%$ & 74,419 & $7 \%$ & 831 & $0 \%$ & 348,550 & $32 \%$ \\
21,063 & $3 \%$ & 6,319 & $1 \%$ & 306 & $0 \%$ & 27,688 & $4 \%$ \\
6,288 & $2 \%$ & 1,713 & $1 \%$ & 575 & $0 \%$ & 8,575 & $3 \%$ \\
2,250 & $2 \%$ & 338 & $0 \%$ & 6 & $0 \%$ & 2,594 & $3 \%$ \\
38 & $0 \%$ & 119 & $0 \%$ & 0 & $0 \%$ & 156 & $1 \%$ \\
0 & $0 \%$ & 0 & $0 \%$ & 0 & $0 \%$ & 0 & $0 \%$ \\
26,413 & $5 \%$ & 4,969 & $1 \%$ & 450 & $0 \%$ & 31,831 & $6 \%$ \\
14,181 & $8 \%$ & 3,100 & $2 \%$ & 400 & $0 \%$ & 17,681 & $10 \%$ \\
41,300 & $38 \%$ & 18,206 & $17 \%$ & 9,188 & $8 \%$ & 68,694 & $63 \%$ \\
413 & $1 \%$ & 75 & $0 \%$ & 0 & $0 \%$ & 488 & $2 \%$ \\
6 & $0 \%$ & 25 & $1 \%$ & 0 & $0 \%$ & 31 & $1 \%$ \\
0 & $0 \%$ & 0 & $0 \%$ & 0 & $0 \%$ & 0 & $0 \%$ \\
\hline
\end{tabular}

Negative values denote net wetland losses in an ecoregion, while positive values represent net wetland gains FWMS fresh water mineral soil

${ }^{\text {a }}$ Percent represents the percentage of wetlands changed to a specific land cover type in 2050 relative to modeled 2010 wetland areas 
Table 2 Mean soil organic carbon (SOC) $\left(\mathrm{MgC} \mathrm{ha}^{-1}\right)$ for four wetland types according to level III ecoregion, land capability class and cropland cash rent value

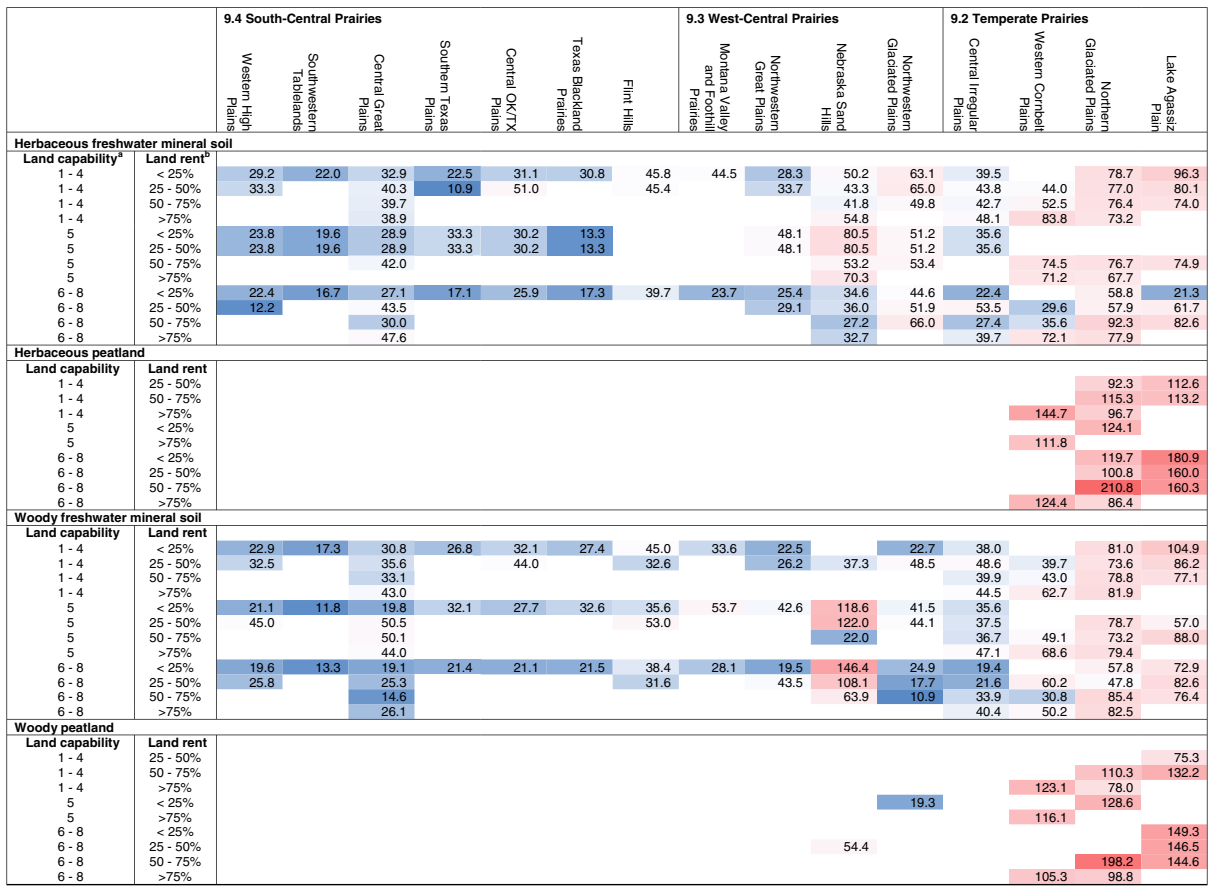

Lower carbon content is in blue and higher carbon content is in red. In the Great Plains, SOC increases from west to east, with highest average values in the Northern Glaciated Plains and Lake Agassiz Plain, where peatlands are present. Source: Soil Survey Staff 2009a, b, USDA NASS 2012a, b

a Land capability classes: 1-4: few to severe limitations to cropland; 5: limitations to cropland difficult to remove (e.g. wetness); 6-8: not suitable for cropland

${ }^{\mathrm{b}}$ Land rent classes: $<25 \%$ : lands in the bottom 25 percentile of cropland value; $25-50 \%$ : lands in the 25 to 50 percentile of cropland value; $50-75 \%$ : lands in the 50 to 75 percentile of cropland value; $>75 \%$ : lands in the top 75 percentile of cropland value

wetland avoided loss. Therefore, we show a range of possible outcomes by defining avoided loss scenarios. For example, if incentives for preserving carbon are strong, then lands falling within the top 10th percentile or quartiles of carbon stocks may be prioritized for avoided loss.

\subsubsection{Carbon scenarios - wetlands with the highest SOC stocks}

In these cases, wetlands with SOC in the highest 10th percentile and highest quartile of all wetlands converted in the A1B and A2 scenarios were selected for avoided loss. For the highest quartile case, 12.6 teragrams of carbon $(\mathrm{TgC})$ are protected in $\mathrm{A} 1 \mathrm{~B}$ and $7.0 \mathrm{TgC}$ are protected in A2. These wetlands are predominantly found in the Temperate Prairies, with most located in the Northern Glaciated Plains level III ecoregion (6.2 TgC; A1B upper quartile scenario) (Table 4). Of these selected Northern Glaciated Plains wetlands, approximately $90 \%$ were herbaceous FWMS for both scenarios and percentiles, and the remaining were divided between herbaceous peatland and woody FWMS wetlands. The 
Table 3 Mean woody biomass carbon $\left(\mathrm{MgC} \mathrm{ha}^{-1}\right)$ for two woody wetland types according to level III ecoregion, land capability class and cropland cash rent value

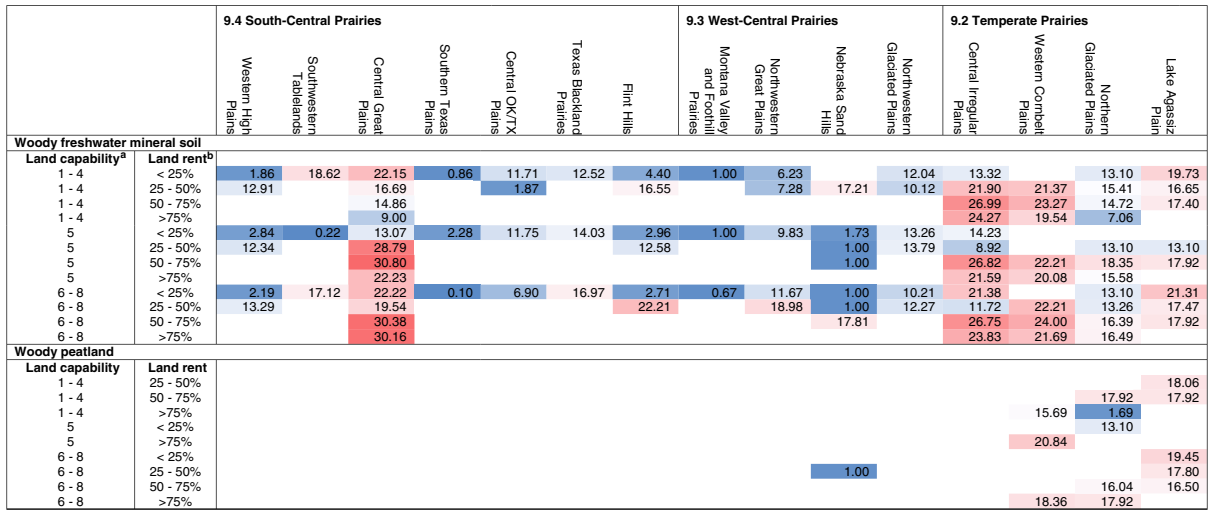

Lower carbon content is in are blue and higher carbon content is in red. Highest average woody biomass carbon is found in the Central Great Plains and Central Irregular Plains ecoregions. Source: Blackard et al. 2008, Zhu et al. 2011

a Land capability classes: 1-4: few to severe limitations to cropland; 5: limitations to cropland difficult to remove (e.g. wetness); 6-8: not suitable for cropland

${ }^{\mathrm{b}}$ Land rent classes: $<25 \%$ : lands in the bottom 25 percentile of cropland value; $25-50 \%$ : lands in the 25 to 50 percentile of cropland value; $50-75 \%$ : lands in the 50 to 75 percentile of cropland value; $>75 \%$ : lands in the top 75 percentile of cropland value

highest ecoregional average SOC was $162.2 \pm 1.2 \mathrm{MgC} \mathrm{ha}^{-1}$, found in the Lake Agassiz Plain for the upper 10th percentile A1B case (Fig. 3).

\subsubsection{Carbon scenarios - wetlands with the lowest SOC stocks}

In these cases, wetlands with SOC in the lowest 10th percentile and lowest quartile of all wetlands converted in the A2 and A1B scenarios were selected for avoided loss. In the lower quartile case, $2.3 \mathrm{TgC}$ are protected in $\mathrm{A} 1 \mathrm{~B}$ and $1.3 \mathrm{TgC}$ are protected in $\mathrm{A} 2$. When examining the wetlands with the lowest carbon stocks, level III ecoregions in the WestCentral and South-Central Semi-Arid Prairies are consistently ranked as having the greatest area of low-carbon wetlands. Maximum avoided loss for low SOC stocks were in the Central Great Plains in the lowest 10th percentile case $(0.08 \mathrm{TgC}$; A1B scenario) and the Nebraska Sand Hills in the lowest quartile case $(0.45 \mathrm{TgC}$; A1B scenario). The Central Great Plains wetlands were $95 \%$ woody FWMS wetlands and the Nebraska Sand Hill wetlands were entirely herbaceous FWMS wetlands.

\subsubsection{Carbon scenarios - wetlands with the highest woody biomass C stocks}

In these cases, wetlands with woody biomass $C$ in the highest 10th percentile and highest quartile of all wetlands converted in the $\mathrm{A} 2$ and $\mathrm{A} 1 \mathrm{~B}$ scenarios were selected for avoided loss. For the upper quartile case, $0.55 \mathrm{TgC}$ are protected in $\mathrm{A} 1 \mathrm{~B}$ and $0.34 \mathrm{TgC}$ are protected in A2. Again, these wetlands are predominantly found in the Temperate Prairies, with most located in the Central Great Plains level III ecoregion (0.42 TgC; upper quartile A1B scenario) (Table 5). The highest ecoregional average woody biomass $\mathrm{C}$ was $101.27 \pm 1.17 \mathrm{MgC} \mathrm{ha}^{-1}$, in 


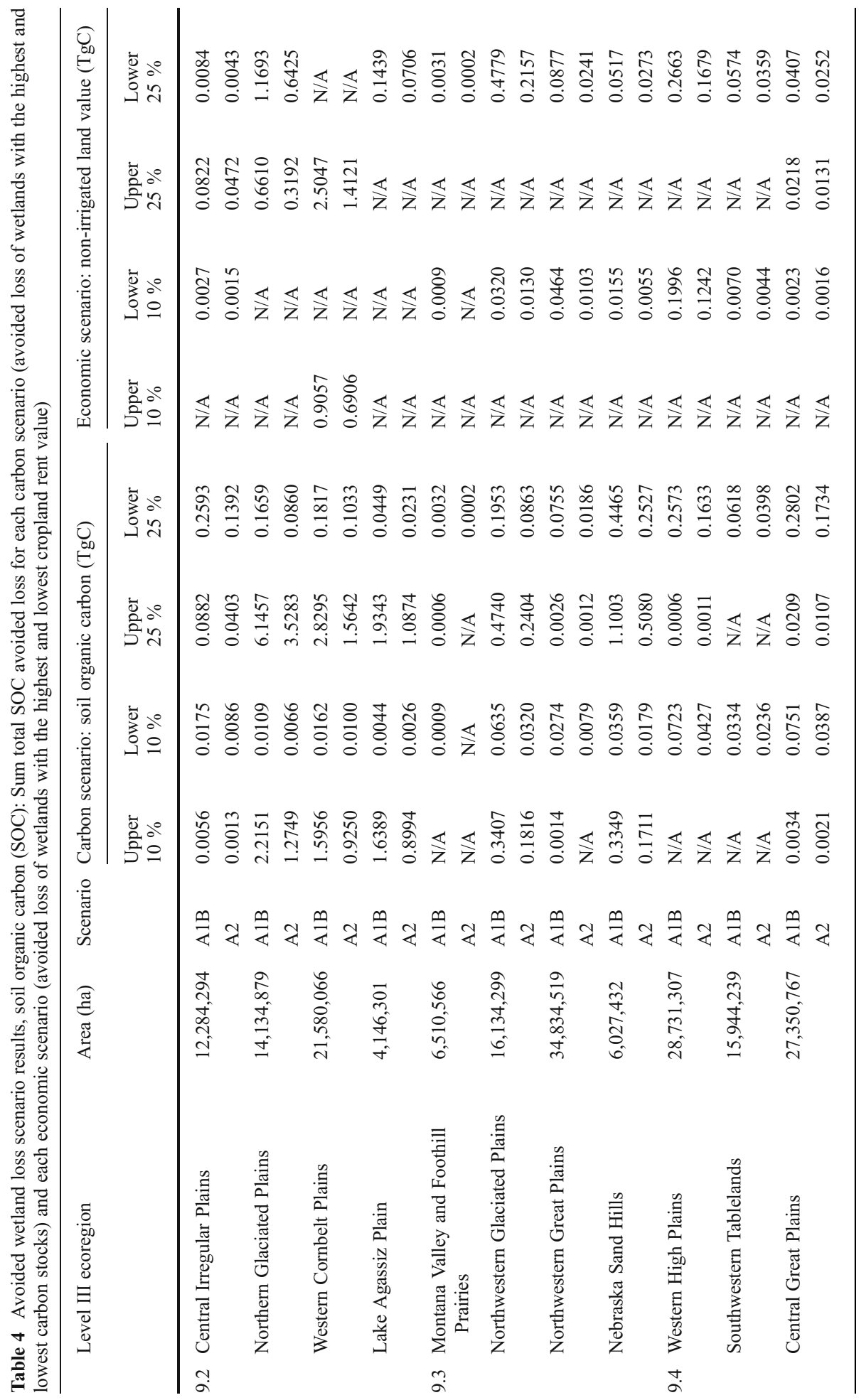




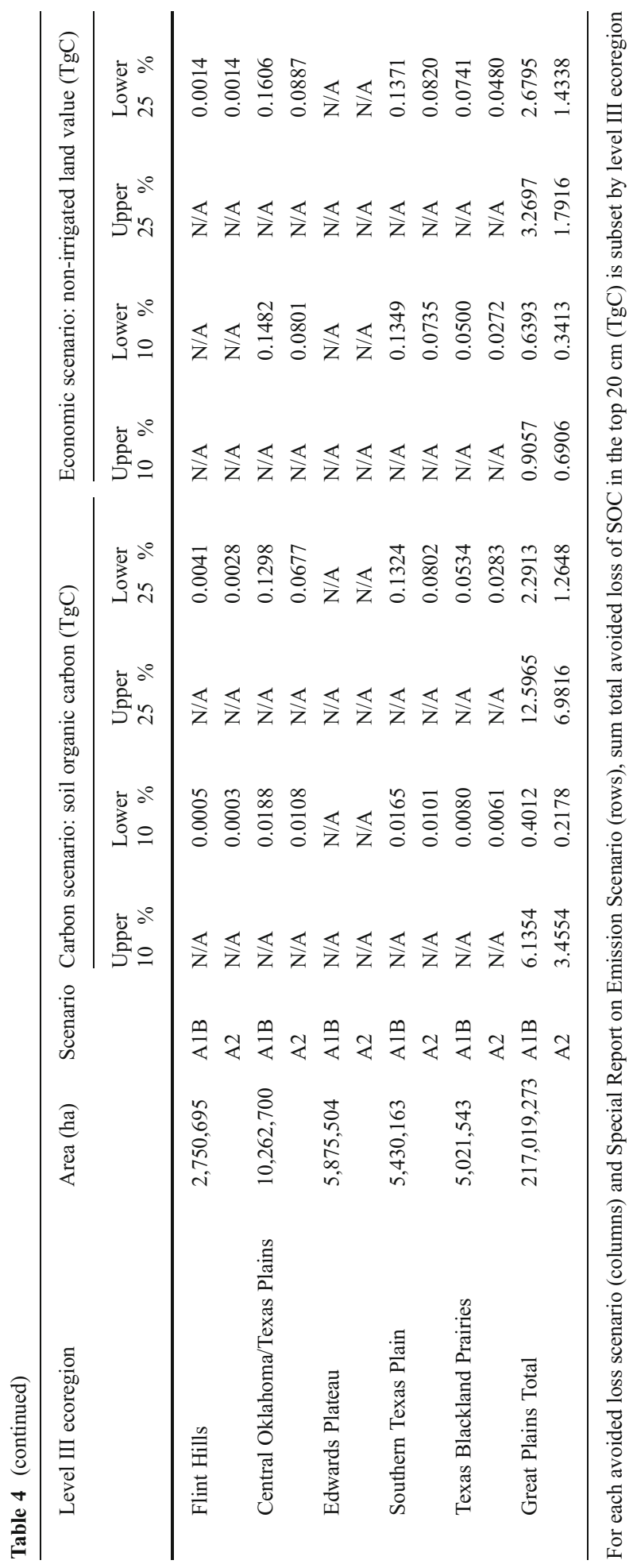


A) Average soil organic carbon content $\left(\mathrm{MgC} \mathrm{ha}^{-1}\right)$
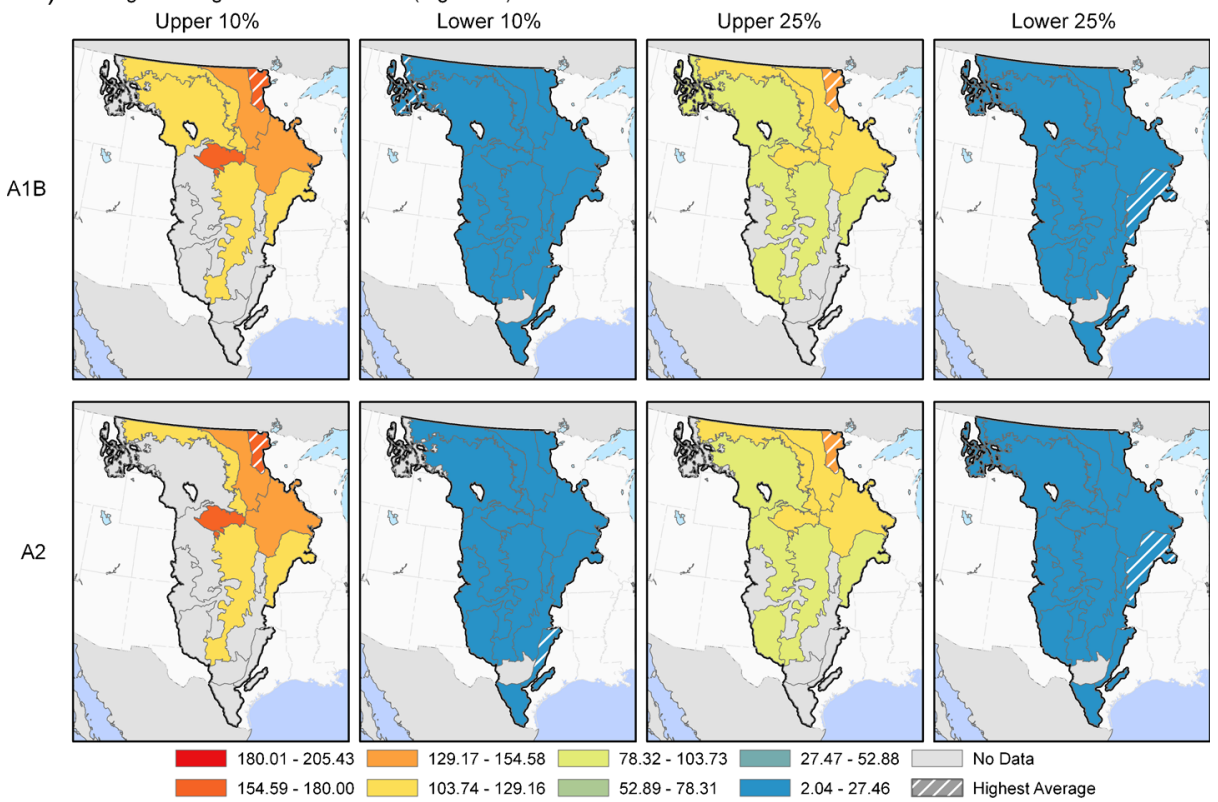

B) Average living aboveground biomass carbon content $\left(\mathrm{MgC} \mathrm{ha}^{-1}\right)$
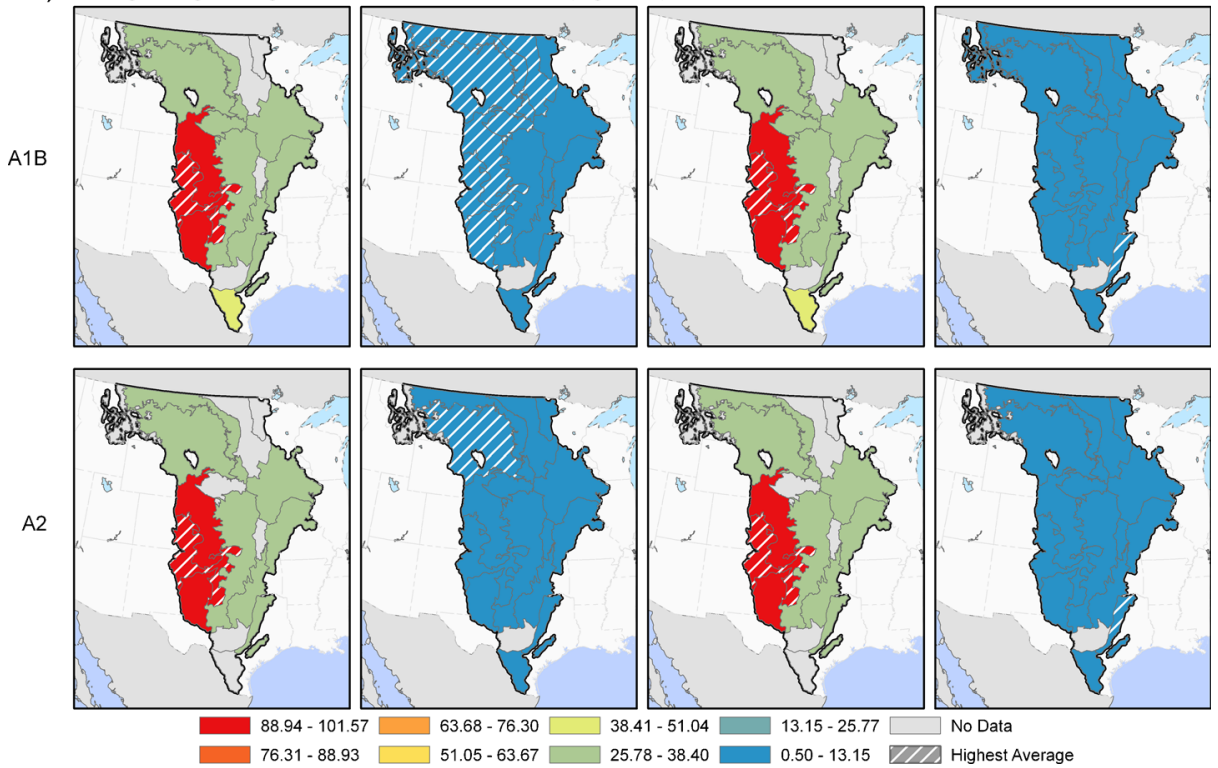

Fig. 3 Avoided wetland loss, carbon scenarios: Average carbon content $\left(\mathrm{MgC} \mathrm{ha}^{-1}\right)$ by level III ecoregion and Special Report on Emission Scenarios A1B and A2 for wetlands selected in each carbon scenario (avoided loss of wetlands with the highest and lowest carbon stocks). a Average soil organic carbon content; b average woody biomass carbon content. Hatch marks represent the ecoregion with the highest average carbon content

the Southwestern Tablelands for the upper 10th percentile A1B case (Fig. 3). All of these wetlands are woody FWMS wetlands. 


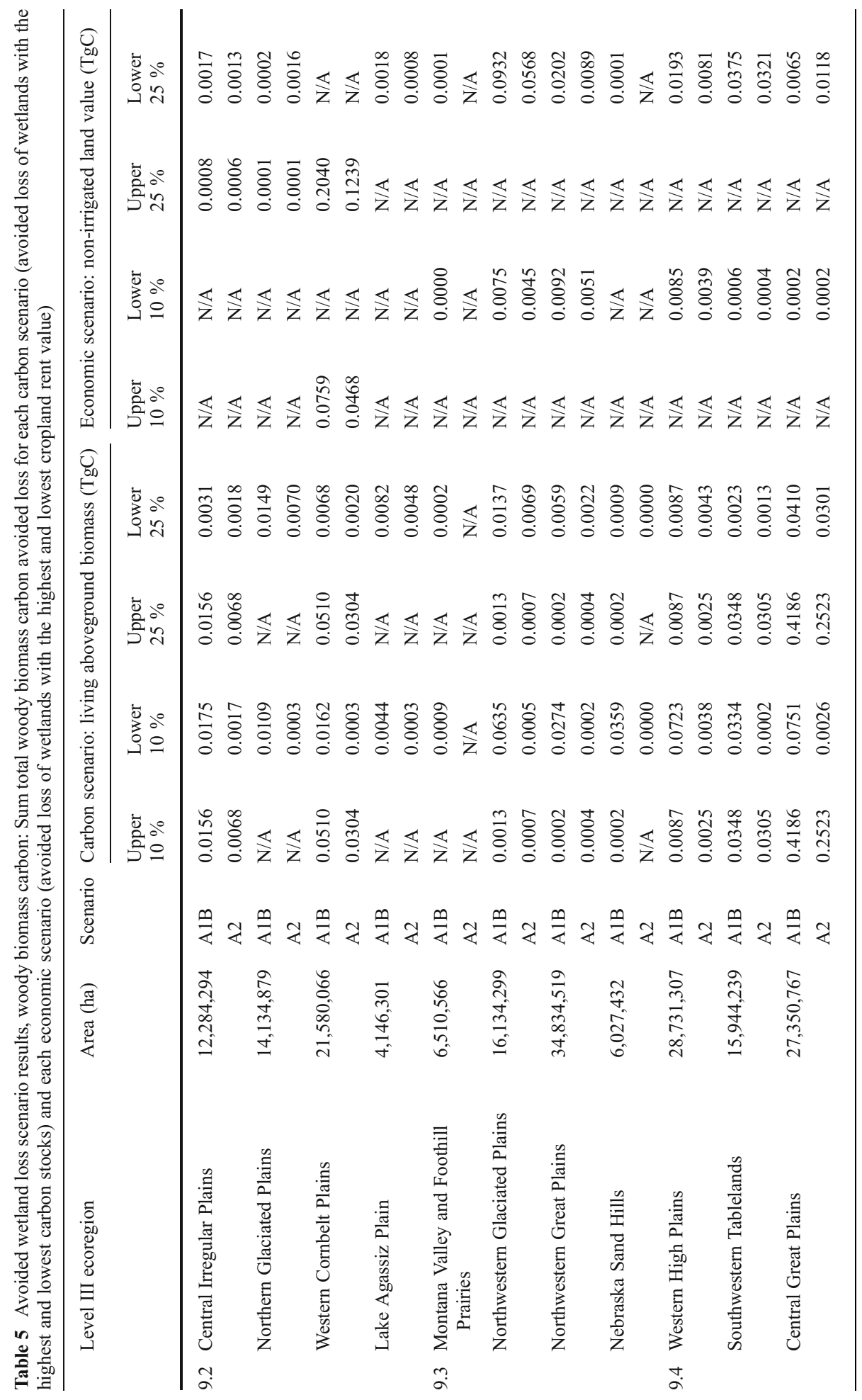




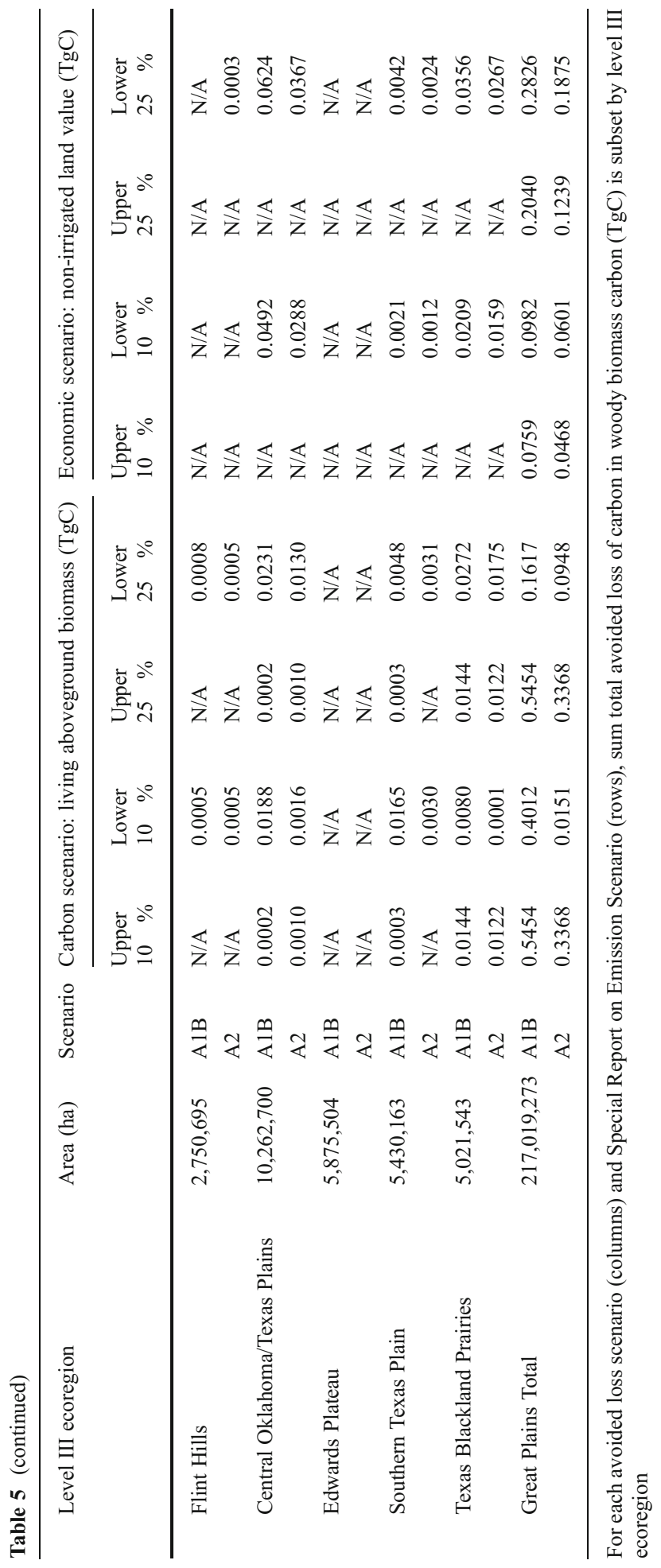


A) Non-irrigated land value - average soil organic carbon content ( $\left.\mathrm{MgC} \mathrm{ha}{ }^{-1}\right)$
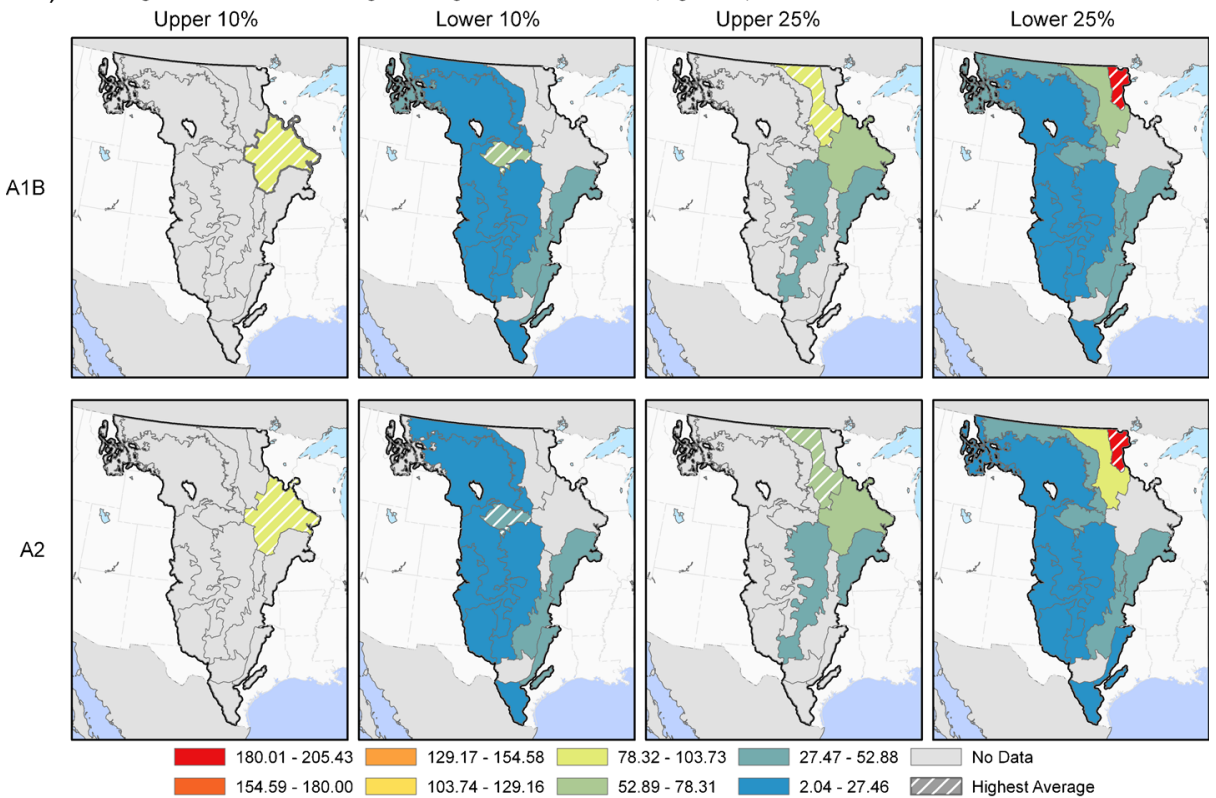

B) Non-irrigated land value - average living aboveground biomass carbon content ( $\left.\mathrm{MgC} \mathrm{ha}^{-1}\right)$
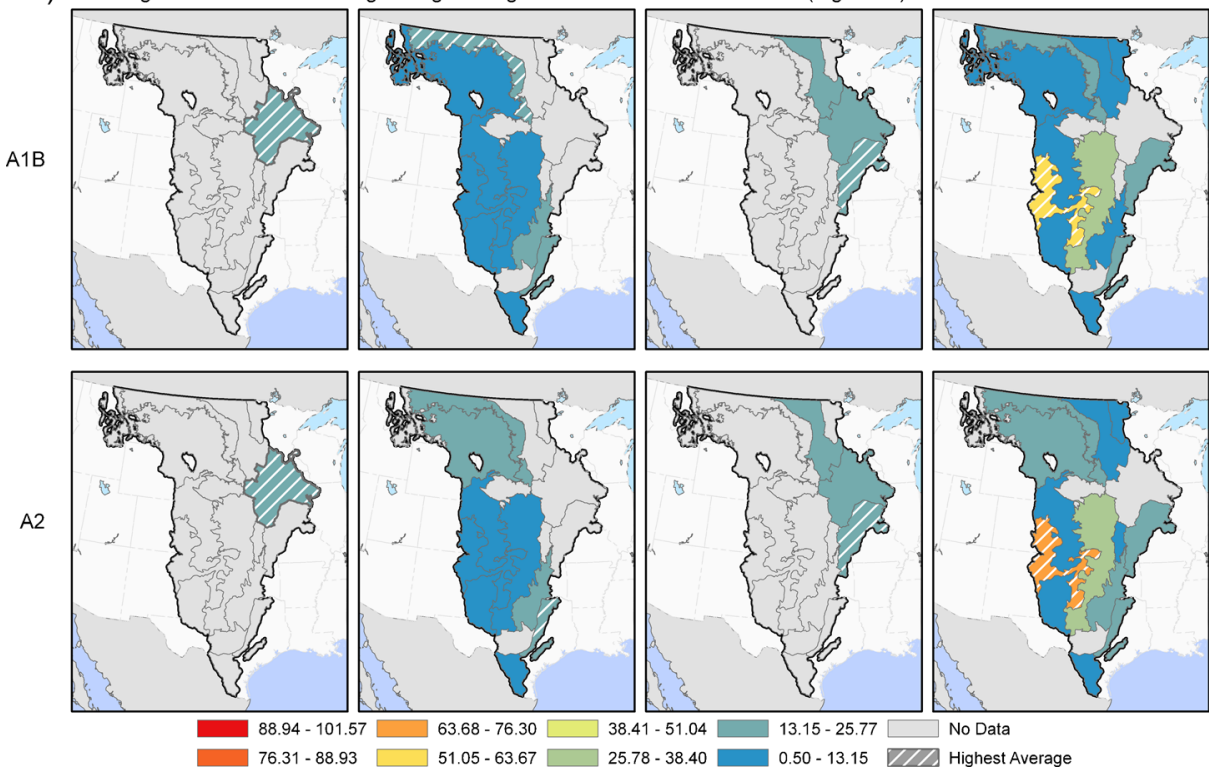

Fig. 4 Avoided wetland loss, economic scenarios: Average carbon content $\left(\mathrm{MgC} \mathrm{ha}^{-1}\right)$ by level III ecoregion and Special Report on Emission Scenarios A1B and A2 for wetlands selected in each economic scenario (avoided loss of wetlands with the highest and lowest cropland rent value). a Average soil organic carbon content; b average woody biomass carbon content. Hatch marks represent the ecoregion with the highest average carbon content 


\subsubsection{Carbon scenarios - wetlands with the lowest woody biomass $C$ stocks}

In these cases, wetlands with woody biomass $\mathrm{C}$ in the lowest 10 th percentile and lowest quartile of all wetlands converted in the $\mathrm{A} 2$ and $\mathrm{A} 1 \mathrm{~B}$ scenarios were selected for avoided loss. For the lower quartile case, $0.16 \mathrm{TgC}$ are protected in $\mathrm{A} 1 \mathrm{~B}$ and $0.09 \mathrm{TgC}$ are protected in $\mathrm{A} 2$.

\subsubsection{Economic scenarios - wetlands with the highest cropland rent value and land capability}

In these cases, wetlands with rent value in the highest 10th percentile and highest quartile of all wetlands converted in the A2 and A1B scenarios were selected for avoided loss. Within the highest quartile of land rents, 3.3 Tg SOC and $0.20 \mathrm{Tg}$ woody biomass $\mathrm{C}$ are protected in $\mathrm{A} 1 \mathrm{~B}$ and $1.8 \mathrm{Tg} \mathrm{SOC}$ and $0.12 \mathrm{Tg}$ woody biomass $\mathrm{C}$ are protected in A2. The Western Cornbelt Plains held the greatest wetland SOC stocks and greatest woody biomass $\mathrm{C}$ stocks for both SRES scenarios and high percentile cases (SOC: $2.5 \mathrm{TgC}$, woody biomass C: $0.20 \mathrm{TgC}$, upper quartile $\mathrm{A} 1 \mathrm{~B}$ scenario) (Tables 4 and 5). The highest ecoregional average SOC was $78.46 \pm 0.81 \mathrm{MgC} \mathrm{ha}^{-1}$, found in the Western Cornbelt Plain for the upper 10th percentile A1B case (Fig. 4). The highest average woody biomass C was $19.39 \pm 0.20 \mathrm{MgC}$ $\mathrm{ha}^{-1}$, found in the Western Cornbelt Plain for the upper 10th percentile A1B case (Fig. 4). Most of these SOC stocks were held in herbaceous FWMS wetlands (54\% for the upper 10 th percentile, $53 \%$ for the upper quartile). The remaining SOC stocks were found in woody FWMS wetlands (47\% for both upper 10th percentile and quartile). Most (95\%) of the woody biomass $\mathrm{C}$ stocks were held in woody FWMS wetlands.

\subsubsection{Economic scenarios - wetlands with the lowest cropland rent value and land capability}

In these cases, wetlands with rent value in the lowest 10th percentile and lowest quartile of all wetlands converted in the A2 and A1B scenarios were selected for avoided loss. Within the lowest quartile of land rents, $2.7 \mathrm{TgC} \mathrm{SOC}$ and $0.28 \mathrm{TgC}$ woody biomass $\mathrm{C}$ are protected in $\mathrm{A} 1 \mathrm{~B}$ and $1.4 \mathrm{TgC}$ SOC and $0.19 \mathrm{TgC}$ woody biomass $\mathrm{C}$ are protected in $\mathrm{A} 2$. For the lower 25th percentile land value, A1B case, the Northern Glaciated Plains held the greatest SOC stocks $(1.17 \mathrm{TgC})$ and the Northwestern Glaciated Plains held the greatest woody biomass $\mathrm{C}$ stocks $(0.093 \mathrm{TgC})$. The Western Cornbelt Plains, a region of high land rent, did not contain any wetlands meeting the criteria for the low land rent scenarios.

\subsection{Case studies of potential carbon loss}

The average annual SOC loss, during 30 years of conversion, is $0.20 \pm 0.15$ megagrams of carbon per hectare per year $\left(\mathrm{MgC} \mathrm{ha}^{-1} \mathrm{yr}^{-1}\right)$ in the $\mathrm{A} 1 \mathrm{~B}$ scenario and $0.21 \pm 0.23 \mathrm{MgC}$ $\mathrm{ha}^{-1} \mathrm{yr}^{-1}$ in the $\mathrm{A} 2$ scenario (Fig. 5). The average SOC loss after 30 years conversion is 6.11 $\mathrm{MgC} \mathrm{ha}^{-1}$ in the $\mathrm{A} 1 \mathrm{~B}$ scenario and $6.32 \mathrm{MgC} \mathrm{ha}^{-1}$ in $\mathrm{A} 2$ scenario. The total loss of $\mathrm{SOC}$ in the Temperate Prairies is $0.88 \mathrm{TgC}$ in the $\mathrm{A} 1 \mathrm{~B}$ scenario and $0.32 \mathrm{TgC}$ in the $\mathrm{A} 2$ scenario. The greater wetland area converted in the A1B scenario is the major cause of greater SOC loss in A1B scenario.

The average annual TEC loss is larger than the SOC loss during 30 years of conversion due to the removal of woody biomass $\mathrm{C}$ (Fig. 5). The average TEC loss is $0.50 \pm 0.45 \mathrm{MgC}$ $\mathrm{ha}^{-1} \mathrm{yr}^{-1}$ in the A1B scenario and $0.81 \pm 0.41 \mathrm{MgC} \mathrm{ha}^{-1} \mathrm{yr}^{-1}$ in the A2 scenario. The average 


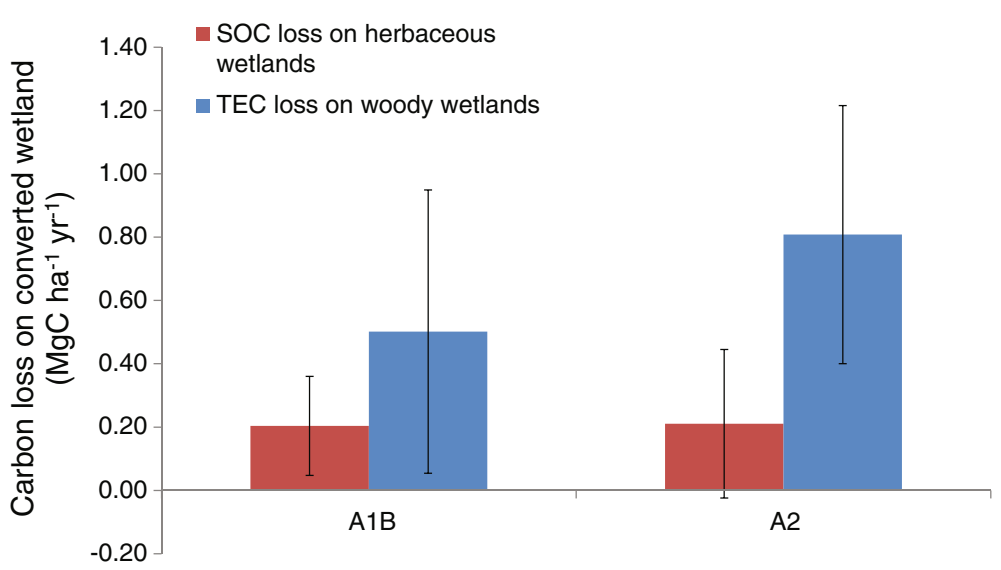

Fig. 5 Average and standard deviation of 30-year soil organic carbon (SOC) and total ecosystem carbon (TEC) change ( $\left.\mathrm{MgC} \mathrm{ha}^{-1} \mathrm{yr}^{-1}\right)$ by Special Report on Emission Scenario (A2 and A1B), as modeled by the ErosionDeposition Carbon Model

TEC loss after 30 years conversion is $15.05 \mathrm{MgC} \mathrm{ha}^{-1}$ in the $\mathrm{A} 1 \mathrm{~B}$ scenario and $24.24 \mathrm{MgC}$ $\mathrm{ha}^{-1}$ in the A2 scenario. The total loss of TEC in the Temperate Prairies is $1.05 \mathrm{TgC}$ in the $\mathrm{A} 1 \mathrm{~B}$ scenario and $0.90 \mathrm{TgC}$ in the $\mathrm{A} 2$ scenario.

\section{Discussion}

The approach taken in this study to inform climate mitigation strategies is distinguished by 1) the consideration of climate mitigation in the context of LULC change projections, 2) the consideration of competing demands for land use indicated by land capability class and land rents, and 3) the spatial distribution of climate mitigation potential. The application to wetland ecosystems characterized in carbon relevant terms adds to the uniqueness of this effort. By way of example, Eagle and others (2012) produced mitigation potential results for agricultural ecosystems based on current land use with few restrictions on the implementation of strategies, and average rates of carbon sequestration and GHG emission reductions for each mitigation strategy. While competing demands for land use, as indicated by land capability and/or rent is not a novel idea (Lubowski et al. 2006; Niu and Duiker 2006), such analyses have concerned forest ecosystems and not wetland ecosystems known for large carbon pools. In contrast our approach examines the spatial variability of wetland carbon stocks vulnerable to conversion and mitigation potential within a region. This approach, using USGS assessment data may also be applied to other ecosystems such as forests and grasslands, where avoided loss and restoration can also serve as a promising mitigation strategy (Gebhart et al. 1994; Potter 2006; Sauer et al. 2011).

The LULC change results for the Great Plains ecoregion show that high standards of living and technological innovation in the A1B scenario led to high demand for cultivated crops for food and feed, and land devoted to biofuels, including both traditional biofuels and cellulosic biofuels after 2025 (shown by expansion in the "hay/pasture" class) (Sohl et al. 2012). The A2 scenario assumptions of higher population pressures and lower use of biofuels resulted in less hay/pasture expansion and more cultivated crop expansion than the A1B scenario. The B1 scenario also showed agricultural expansion, although at a much 
lower magnitude than the A scenarios. Agricultural expansion was concentrated in a few central Great Plains ecoregions, and this scenario included restoration of wetlands, primarily in the northern Great Plains (Sohl et al. 2012).

Wetland loss in the A1B and A2 scenarios exhibit similar general patterns in wetland loss, both geographically and thematically, by the year 2050. Geographically, wetland loss is highest in the Temperate Prairies, particularly in the Northern Glaciated Plains and Lake Agassiz Plains level III ecoregions. The West-Central Semi-Arid Prairies experienced the second highest wetland loss, with losses concentrated in the Northwestern Glaciated Plains and the eastern part of the Nebraska Sandhills. Wetland losses are lower, scattered, and local in the South-Central Prairies. The primary differences between A1B and A2 include a significantly higher magnitude of wetland loss in A1B, approximately $60 \%$ higher than wetland losses in the A2 scenario (Table 1). Loss of wetland to hay/pasture is proportionally higher in A1B than in A2, due to increased production of cellulosic-based ethanol in the A1B scenario [with cellulosic-based feedstocks such as switchgrass (Panicum virgatum) or Miscanthus sp. classed as hay/pasture]. Woody wetland loss is actually higher in A2 in the South-Central Prairies than it is in the West-Central Semi-Arid Prairies. Other geographic and thematic patterns of change are similar. However, it is important to note that this study only considered changes through the year 2050 and not the full IPCC-SRES projection period through 2100, where the A2 scenario experienced very high rates of agricultural intensification in the Great Plains (Sleeter et al. 2012; Sohl et al. 2012). It is likely that the large demand for agricultural in the latter half of the 21 st century would lead to much larger declines in wetland carbon across all wetland carbon classes for A2 compared to the A1B scenario.

In the carbon and economic scenarios for avoided carbon loss, patterns are also roughly similar between A1B and A2, with the magnitude of carbon "savings" higher in the A1B scenario. According to the criteria of our avoided loss scenarios, across the Great Plains, SOC savings are higher than avoided loss of woody biomass $\mathrm{C}$, primarily due to the greater extent of herbaceous wetlands in the region and therefore greater pools within the top percentiles that we investigated. While the cumulative avoided loss of herbaceous FWMS wetlands contributes most to carbon savings, the highest SOC is found in the herbaceous peatlands of the Northern Glaciated Plains and Lake Agassiz Plains.

Given the lower amount of wetland loss and the lower mean SOC in the South-Central Prairies, the Temperate Prairies and West-Central Prairies are likely the most suitable locations to maximize avoided carbon loss. However, when examining the results of the economic scenarios, high cropland rents in parts of the Temperate Prairies and West-Central Prairies may make avoided loss economically infeasible in some areas. For example, the Western Corn Belt Plains offers significant carbon savings in the high carbon scenarios, but the dominance of the ecoregion in the high land-value economic scenarios demonstrates that avoided loss in the ecoregion would come with a significant economic cost. Like the Western Corn Belt Plains, the Northern Glaciated Plains and Lake Agassiz Plains exhibit very high mean SOC (Table 3). These two ecoregions also provide significant carbon savings through avoided loss in the high carbon scenarios, yet when compared to the Western Corn Belt Plains in the economic scenarios, land rents are, on average, lower, which may create more economically competitive opportunities for avoided carbon loss.

Between the A1B and A2 scenarios, the much higher demand for agricultural land use in the A1B scenario likely make avoided loss less feasible than in A2, especially in the early decades of this century. In A1B, even many marginal agricultural lands are converted to cropland or hay/pasture, resulting in relatively few suitable, alternative locations for establishment of agricultural land, in lieu of wetland conversion. Lowered demand for agricultural 
land use in A2 will likely result in more alternative choices for establishing new agricultural fields than in A1B, allowing for increased opportunities for avoided loss through conservation of wetlands. In the A1B scenario, conversion of wetlands to hay/pasture is proportionally higher than in A2, and because of this increased demand, and because of the lower value of pastureland compared to cropland, strategies for wetland avoided loss may need to target lands suitable for this specific LULC conversion. These strategies may be suitable in the Northern Glaciated Plains and the eastern part of the Nebraska Sandhills, where wetland conversion to hay/pasture occurs frequently in the A1B scenario (and to a lesser extent, in the A2 scenario), and where mean SOC offers potentially significant carbon savings.

The SOC loss $\left(\sim 6 \mathrm{MgC} \mathrm{ha}^{-1}\right)$ from wetlands simulated by EDCM is about $60 \%$ of the SOC loss $\left(10.1 \mathrm{Mg} \mathrm{ha}^{-1}\right)$ estimated from the field studies in the prairie pothole region (Euliss et al. 2006). The lower SOC loss estimated by EDCM was expected because the simulation scenario was set up with optimized management practices on croplands to reduce SOC loss. The assessment assumed that conservation tillage (leaving the previous year's crop residue on fields) would be applied on converted cropland to minimize soil erosion on the surface and maximize crop residue returns. These assumptions are different than the actual management practices performed in the field from past decades. Historically when wetlands were converted to croplands, excess water was removed by open ditching, tile drainage or both in this region (Dahl and Johnson 1991), which increased soil erosion (Newson 1980; Holden 2006). Conventional tillage (disking or plowing crop residue left after the harvest) was the dominant tillage applied in this region before 1990s (West et al. 2008), and carbon sequestration rates on cropland under conventional tillage are lower than on cropland under conservation tillage in the long term (West and Post 2002; Ogle et al. 2005). Thus, the conversion of wetlands with mineral soil to croplands will likely lose more SOC than our estimates in these scenarios.

Here we present EDCM-simulated SOC change on wetlands with mineral soils. Wetlands with organic soil may lose much greater SOC upon cropland conversion. A synthesis study concluded that the SOC loss rate of organic soil is $11 \pm 2.5 \mathrm{MgC} \mathrm{ha}^{-1} \mathrm{yr}^{-1}$ for cool temperate regions and can be as high as $14 \pm 2.5 \mathrm{MgC} \mathrm{ha}^{-1} \mathrm{yr}^{-1}$ for warm temperate regions after land use change (Ogle et al. 2003). The default annual emission factors used by IPCC for cultivated organic soil ranged between 5 and $20 \mathrm{MgC} \mathrm{ha}^{-1} \mathrm{yr}^{-1}$ in different climatic regions (IPCC 2006). These high loss rates are greatly attributed to enhanced soil decomposition when the organic soil environment is converted from anaerobic to aerobic after drainage (McLatchey and Reddy 1998; Couwenberg et al. 2010). Wind and water erosion may also cause substantial loss of SOC on these wetlands but field measurements are not yet available to assess these impacts.

There are multiple potential sources of error in the estimates provided here, due to the land-cover mapping and modeling methodologies that were used. The NLCD was selected as baseline LULC data for the USGS assessment and our wetland maps because it serves as a consistent, moderate resolution map for the U.S. with LULC classes suitable for modeling ecosystem change. The NLCD was derived from Landsat satellite imagery and ancillary data. For wetlands, more detailed National Wetlands Inventory Maps (NWI) were applied where available. Where NWI was lacking, modeling was used to estimate wetlands in these localized areas (Vogelmann et al. 1998a, b). However satellite imagery is less able to detect small or long and narrow wetlands (Ozesmi and Bauer 2002), and prairie potholes, for example, can be less than one acre ( $0.4 \mathrm{ha})$ in size, smaller than our mapping unit of 6.25 ha (Euliss et al. 1999). In addition wetland boundaries are dynamic and fluctuate both inter- and intra-annually depending on factors such as rainfall, evaporation, groundwater flow and land use manipulation (Corcoran et al. 2011). As a result, wetland map accuracies in NLCD are lower than other LULC classes, and accuracies are more spatially variable. 
Outside of baseline data used for this work, the scenario construction process and the spatial modeling introduce a significant source of uncertainty. Each scenario represents but one possible future, an interpretation of the future landscape under a defined set of socioeconomic and biophysical conditions. The use of multiple scenarios is meant to bound overall uncertainty in future LULC proportions. The spatial model itself introduces another potential source of uncertainty as it ultimately controls the spatial configuration of LULC projections. Initially in the modeling process, variation in spatial allocation of LULC may outweigh scenario differences, but as the simulation period increases, differences in scenarios emerge and become increasingly important (Sohl et al. 2012). Given sources of pixellevel uncertainty in baseline data and modeling, we report findings at the level III ecoregion scale.

At the ecoregion scale, we identify wetland regions across the Great Plains that are vulnerable to loss across multiple future scenarios, as well as the average carbon stocks and land values of these regions. Our results highlight regions where there are potential opportunities for the climate change mitigation strategy of wetland avoided loss, as well as regions where constraints may exist due to high demand for agriculture and high land value. In the Great Plains, numerous organizations are partnering to establish an SOC bank through acquisition of conservation easements (Ducks Unlimited Inc. et al. 2009). Consideration of threat of conversion, as well as cost and biological benefits (such as carbon) has been shown to be a successful strategy for maximizing the avoided loss of these benefits (Newburn et al. 2005, 2006; Merenlender et al. 2009). Our analysis presents a coarse-scale assessment of regional wetland avoided loss potential across a large area. Results can help prioritize field-based assessments, where site-level investigations of carbon stocks, land value, and consideration of local priorities for climate change mitigation programs are needed.

Acknowledgments We thank the editor and co-authors of the USGS Professional Paper 1787, Baseline and projected future carbon storage and greenhouse-gas fluxes in the Great Plains region of the United States: Zhiliang Zhu (editor), Michelle Bouchard, David Butman, Todd Hawbaker, Jinxun Liu, Shuguang Liu, Cory McDonald, Ryan Reker, Kristi Sayler, and Sarah Stackpoole for developing the scenarios, land use change and biogeochemical model outputs used in this study. We also thank Brian Bergamaschi (USGS), LisamarieWindham Myers (USGS) and Jessica O'Connell (U.C. Berkeley) for their assistance in developing this project, and we thank Michael Hooper (USGS) for reviewing the draft manuscript.

Any use of trade, firm, or product names is for descriptive purposes only and does not imply endorsement by the U.S. Government.

Open Access This article is distributed under the terms of the Creative Commons Attribution License which permits any use, distribution, and reproduction in any medium, provided the original author(s) and the source are credited.

\section{References}

Badiou P, Mcdougal R, Pennock D et al (2011) Greenhouse gas emissions and carbon sequestration potential in restored wetlands of the Canadian prairie pothole region. Wetl Ecol Manag 19:237-256

Blackard JA, Finco MV, Helmer EH et al (2008) Mapping U.S. forest biomass using nationwide forest inventory data and moderate resolution information. Remote Sens Environ 112:1658-1677

Bliss NB (2003) Soil organic carbon on lands of the Department of the Interior, USGS Open-File Report 03304. U.S. Geological Survey. http://egsc.usgs.gov/isb/pubs/openfile/OFR03-304.pdf. Cited 24 Jan 2013

Bridgham SD, Megonigal JP, Keller JK et al (2006) The carbon balance of North American wetlands. Wetlands 26:889-916 
Climate Action Reserve (2011) Program Manual. http://www.climateactionreserve.org/how/program/programmanual/. Cited 12 Dec 2012

Commission for Environmental Cooperation, Mcginley M (2008) Great plains ecoregion. In: Cleveland CJ (ed) Encyclopedia of earth. Environmental Information Coalition, National Council for Science and the Environment, Washington D.C

Corcoran J, Knight J, Brisco B et al (2011) The integration of optical, topographic, and radar data for wetland mapping in northern Minnesota. Can J Remote Sens 37:564-582

Couwenberg J, Dommain R, Joosten H (2010) Greenhouse gas fluxes from tropical peatlands in south-east Asia. Glob Chang Biol 16:1715-1732

Crooks S, Emmett-Mattox S, Findsen J (2010) Findings of the National Blue Ribbon Panel on the development of a greenhouse gas offset protocol for tidal wetlands restoration and management: Action plan to guide protocol development. Restore America's Estuaries, Philip Williams \& Associates, Ltd., and Science Applications International Corporation. https://www.estuaries.org/images/stories/rae-actionplan-tidal-wetlandsghg-offset-protocol-aug-2010.pdf. Cited 1 Aug 2011

Dahl TE, Johnson CE (1991) Status and trends of wetlands in the conterminous United States, mid-1970's to mid1980's. U.S. Department of Interior Fish and Wildlife Service. http://www.fws.gov/wetlands/Documents/ Wetlands-Status-and-Trends-in-the-Conterminous-United-States-Mid-1970s-to-Mid-1980s.pdf. Cited 16 Feb 2013

Ducks Unlimited Inc, New Forests Inc, Equator Llc (2009) Ducks Unlimited avoided grassland conversion project in the Prairie Pothole region; climate, community and biodiversity alliance report. Ducks Unlimited, Bismark

Eagle A, Olander L, Henry LR et al (2012) Greenhouse gas mitigation potential of agricultural land management in the United States: A synthesis of the literature. Report NI R 10-04, Third Edition. Nicholas Institute for Environmental Policy Solutions, Duke University, Durham, NC

Encyclopædia Britannica Online (2013) Great Plains. http://www.britannica.com/EBchecked/topic/243562/ Great-Plains. Cited 1 July 2013

Euliss NH, Gleason RA, Olness A et al (2006) North American prairie wetlands are important nonforested land-based carbon storage sites. Sci Total Environ 361:179-188

Euliss NH, Mushet DM, Wrubleski DA (1999) Wetlands of the prairie pothole region: invertebrate species composition and management, Chapter 21. In: Batzer DP, Rader RB, Wissinger SA (eds) Invertebrates in freshwater wetlands of North America: ecology and management. Wiley, New York, pp 471-514

Gebhart DL, Johnson HB, Mayeux HS et al (1994) The CRP increases soil organic carbon. J Soil Water Conserv 49:488-499

Gleason RA, Euliss NH, Tangen BA et al (2011) USDA conservation program and practice effects on wetland ecosystem services in the prairie pothole region. Ecol Appl 21:S65-S81

Harvey CA, Zerbock O, Papageorgiou S et al (2010) What is needed to make REDD+ work on the ground? Lessons learned from pilot forest carbon initiatives. Conservation International. http://www.conservation.org/ learn/climate/pages/publications.aspx. Cited 1 Nov 2012

Holden J (2006) Sediment and particulate carbon removal by pipe erosion increase over time in blanket peatlands as a consequence of land drainage. J Geophys Res Earth Surf 111:F02010

Homer C, Dewitz J, Fry J et al (2007) Completion of the 2001 National Land Cover Database for the conterminous United States. Photogramm Eng Remote Sens 73:337-341

Houghton RA (2010) How well do we know the flux of $\mathrm{CO}_{2}$ from land-use change? Tellus B 62:337-351

IPCC (2006) Cropland. In: Eggleston HS, Buendia L, Miwa K et al (eds) IPCC guidelines for national greenhouse gas inventories, Volume IV, Chapter 5. National Greenhouse Gas Inventories Programme, Japan, pp 5.1-5.66

Kollmuss A, Lazarus M, Lee C et al (2010) Handbook of carbon offset programs - trading systems, funds, protocols and standards. Earthscan. http://www.knovel.com/web/portal/browse/display?_EXT_KNOVEL_ DISPLAY bookid=3247. Cited 12 Feb 2013

Lal R (2004) Soil carbon sequestration to mitigate climate change. Geoderma 123:1-22

Landfire (2012) LANDFIRE 1.1.0 Existing Vegetation Type layer. U.S. Department of the Interior, Geological Survey. http://landfire.cr.usgs.gov/viewer. Cited 9 Apr 2012

Liu S, Bliss NB, Sundquist E et al (2003) Modeling carbon dynamics in vegetation and soil under the impact of soil erosion and deposition. Global Biogeochem Cycles 17:1074

Liu S, Liu J, Young CJ et al (2012a) Chapter 5. Baseline carbon storage, carbon sequestration, and greenhouse-gas fluxes in terrestrial ecosystems of the Western United States. In: Zhu Z, Reed BC (eds) Baseline and projected future carbon storage and greenhouse-gas fluxes in ecosystems of the Western United States: U.S. Geological Survey Professional Paper 1797. pp 1-20

Liu S, Tan Z, Chen M et al (2012b) The general ensemble biogeochemical modeling system (GEMS) and its applications to agricultural systems in the United States. In: Liebig MA, Franzluebbers AJ, Follett RF 
(eds) Managing agricultural greenhouse gases: coordinated agricultural research through GRACEnet to address our changing climate. Academic, San Diego, pp 309-323

Loveland TR, Sohl TL, Stehman SV et al (2002) A strategy for estimating the rates of recent United States land-cover changes. Photogramm Eng Remote Sens 68:1091-1099

Lubowski RN, Plantinga AJ, Stavins RN (2006) Econometric estimation of the carbon sequestration supply function. J Environ Econ Manag 51:135-152

McLatchey GP, Reddy KR (1998) Regulation of organic matter decomposition and nutrient release in a wetland soil. J Environ Qual 27:1268-1274

Merenlender AM, Newburn D, Reed SE et al (2009) The importance of incorporating threat for efficient targeting and evaluation of conservation investments. Conserv Lett 2:240-241

Mitsch W, Bernal B, Nahlik A et al (2012) Wetlands, carbon, and climate change. Landsc Ecol 1-15

Nakicenovic N, Swart R (eds) (2000) IPCC special report on emission scenarios. Cambridge University Press, Cambridge

Natureserve (2011) International ecological classification standard: terrestrial ecological classifications. Data current as of 31 July 2011. http://www.natureserve.org/publications/usEcologicalsystems.jsp. Cited 1 Nov 2011

Newburn D, Reed S, Berck P et al (2005) Economics and land-use change in prioritizing private land conservation. Conserv Biol 19:1411-1420

Newburn DA, Berck P, Merenlender AM (2006) Habitat and open space at risk of land-use conversion: targeting strategies for land conservation. Am J Agric Econ 88:28-42

Newson M (1980) The erosion of drainage ditches and its effect on bed-load yields in mid-Wales: reconnaissance case studies. Earth Surf Process 5:275-290

Nickerson C, Morehart M, Kuethe T et al (2012) Trends in U.S. farmland values and ownership, EIB-92. U.S. Department of Agriculture, Economic Research Service. http://www.ers.usda.gov/publications/eib-economicinformation-bulletin/eib92.aspx. Cited 2 Feb 2012

Niu X, Duiker SW (2006) Carbon sequestration potential by afforestation of marginal agricultural land in the Midwestern U.S. Forest Ecol Manage 223:415-427

Ogle SM, Breidt FJ, Paustian K (2005) Agricultural management impacts on soil organic carbon storage under moist and dry climatic conditions of temperate and tropical regions. Biogeochemistry 72:87-121

Ogle SM, Jay Breidt F, Eve MD et al (2003) Uncertainty in estimating land use and management impacts on soil organic carbon storage for US agricultural lands between 1982 and 1997. Glob Chang Biol 9:15211542

Omernik JM (1987) Ecoregions of the conterminous United States. Map (scale 1:7,500,000). Ann Assoc Am Geogr 77:118-125

Omernik JM (1995) Ecoregions: a spatial framework for environmental management. In: Davis WS, Simon TP (eds) Biological assessment and criteria: tools for water resource planning and decision making. Lewis Publishers, Boca Raton, pp 49-62

Ozesmi S, Bauer ME (2002) Satellite remote sensing of wetlands. Wetl Ecol Manag 10:381-402

Parton WJ, Schimel DS, Cole CV et al (1987) Analysis of factors controlling soil organic matter levels in Great Plains Grasslands. Soil Sci Soc Am J 51:1173-1179

Parton WJ, Scurlock JMO, Ojima DS et al (1993) Observations and modeling of biomass and soil organic matter dynamics for the grassland biome worldwide. Global Biogeochem Cycles 7:785-809

Potter KN (2006) Soil carbon content after 55 years of management of a Vertisol in central Texas. J Soil Water Conserv 61:338-343

Ramaswamy V, Boucher O, Haigh J et al (2001) Radiative forcing of climate change. In: Houghton JT, Ding Y, Griggs DJ et al (eds) Climate change 2001: the scientific basis. Contribution of working group I to the Third Assessment Report of the Intergovernmental Panel on Climate Change. Cambridge University Press, Cambridge, UK, pp 349-416

Samson FB, Knopf FL (1994) Prairie conservation in North America. BioScience 44:418-442

Sauer TJ, James DE, Cambardella CA et al (2011) Soil properties following reforestation or afforestation of marginal cropland. Plant and Soil 0032-079X:1-16

Sleeter BM, Sohl TL, Bouchard MA et al (2012) Scenarios of land use and land cover change in the conterminous United States: utilizing the special report on emission scenarios at ecoregional scales. Glob Environ Chang 22:896-914

Sohl TL, Sayler KL (2008) Using the FORE-SCE model to project land-cover change in the southeastern United States. Ecol Model 219:49-65

Sohl TL, Sleeter BM, Sayler KL et al (2012) Spatially explicit land-use and land-cover scenarios for the Great Plains of the United States. Agric Ecosyst Environ 153:1-15 
Soil Survey Staff (2009a) Natural Resources Conservation Service, United States Department of Agriculture. Soil Survey Geographic (SSURGO) Databases for the conterminous United States. http://soildatamart.nrcs.usda.gov. Cited 30 Dec 2009

Soil Survey Staff (2009b) Natural Resources Conservation Service, United States Department of Agriculture. U.S. General Soil Map (STATSGO2) for the conterminous United States. http://soildatamart.nrcs.usda.gov. Cited 30 Dec 2009

Strengers B, Leemans R, Eickhout B et al (2004) The land-use projections and resulting emissions in the IPCC SRES scenarios scenarios as simulated by the IMAGE 2.2 model. GeoJournal 61:381-393

U.S. Government Accountability Office (2007) Agricultural conservation: farm program payments are an important factor in landowner's decisions to convert grassland to cropland. Report to Congressional Requesters GAO-07-1054. http://www.gao.gov/highlights/d071054high.pdf. Cited 1 Dec 2012

USDA National Agricultural Statistics Service (2010) Land values and cash rents 2010 summary. http:// usda.mannlib.cornell.edu/MannUsda/viewDocumentInfo.do?documentID=1446. Cited 15 July 2012

USDA National Agricultural Statistics Service (2012a) Acreage Report. http://usda01.library.cornell.edu/ usda/current/Acre/Acre-06-29-2012.pdf. Cited 25 Feb 2013

USDA National Agricultural Statistics Service (2012b) Cash rents by county. http://www.nass.usda.gov/ Surveys/Guide to NASS Surveys/Cash Rents by County/index.asp. Cited 21 Dec 2012

USDA National Agricultural Statistics Service (2012c) Quick Stats, Cash Rent, Non-Irrigated Cropland. http://quickstats.nass.usda.gov/?sector_desc=ECONOMICS\&commodity_desc=RENT\&agg_level_ desc=COUNTY\#AEE48496-4472-30B2-B445-B3DBBEAD33C3. Cited 1 July 2012

USDA Natural Resources Conservation Service (2012) Restoring America's Wetlands: A private lands conservation success story. http://www.nrcs.usda.gov/wps/portal/nrcs/main/national/programs/easements/wetlands/. Cited 12 Dec 2012

USEPA (2005) Greenhouse gas mitigation potential in U.S. Forestry and Agriculture. EPA 430-R-05-006. http://cfpub.epa.gov/si/si_public_record_Report.cfm?dirEntryID=85583. Cited 1 July 2012

Vogelmann JE, Howard SM, Yang L et al (2001) Completion of the 1990s National Land Cover Data Set for the conterminous United States. Photogramm Eng Remote Sens 67:650-652

Vogelmann JE, Sohl T, Campbell PV et al (1998a) Regional land cover characterization using Landsat Thematic Mapper data and ancillary data sources. Environ Monit Assess 51:415-428

Vogelmann JE, Sohl T, Howard SM (1998b) Regional characterization of land cover using multiple sources of data. Photogramm Eng Remote Sens 64:45-47

Wallander S, Claassen R, Nickerson C (2011) The ethanol decade: an expansion of the U.S. corn production, 2000-09, EIB-79. U.S. Department of Agriculture, Economic Research Service. http://www.ers.usda.gov/ publications/eib-economic-information-bulletin/eib79.aspx. Cited 1 Aug 2011

West TO, Brandt CC, Wilson BS et al (2008) Estimating regional changes in soil carbon with high spatial resolution. Soil Sci Soc Am J 72:285-294

West TO, Post WM (2002) Soil organic carbon sequestration rates by tillage and crop rotation. Soil Sci Soc Am J 66:1930-1946

Zhu Z, Bergamaschi B, Bernknopf R et al (2010) A method for assessing carbon stocks, carbon sequestration, and greenhouse-gas fluxes in ecosystems of the United States under present conditions and future scenarios. U.S. Geological Survey Scientific Investigations Report 2010-5233. http://pubs.usgs.gov/sir/ 2010/5233/. Cited 1 Aug 2012

Zhu Z, Bouchard MA, Butman D et al (2011) Baseline and projected future carbon storate and greenhouse-gas fluxes in the Great Plains region of the United States. U.S. Geological Survey Professional Paper 1787. http://pubs.usgs.gov/pp/1787/. Cited 1 Aug 2012 